\title{
Passive Shareholders as a Takeover Defense
}

\author{
Andriy Bodnaruk ${ }^{\dagger}$, Paul Gao ${ }^{\dagger}$, Per Östberg ${ }^{\ddagger}$, and Hayong Yun ${ }^{\dagger}$ \\ February $17^{\text {th }}, 2011$
}

\begin{abstract}
This paper evaluates the effect of shareholder passiveness on the market for corporate control. We find that firms with more passive shareholders (lower ownership per non-institutional shareholder) are less likely to be takeover targets, less likely to be acquired and command higher premiums. Using the adoption of anti-takeover law in Delaware as an exogenous shock to antitakeover protection, we show that the passiveness of shareholder base decreases as the takeover threat subsides. Our findings support the idea that a passive shareholder base is a substitute for other takeover defenses.
\end{abstract}

JEL Codes: G34, G32

Keywords: Mergers and Acquisitions, Ownership Structure, Corporate Governance.

\footnotetext{
${ }^{\dagger}$ Mendoza College of Business, University of Notre Dame.

*University of Zürich, Swiss Finance Institute.

We thank Mike Burkart, Alex Edmans, Stuart Gillan, John McConnell, Paul Schultz, and seminar participants at the State of Indiana Conference for their helpful comments. Östberg acknowledges financial support from NCCR Finrisk. Please address all correspondence to abodnaru@nd.edu.
} 


\section{Introduction}

In August of 2005, when Carl Icahn proposed to split up Time Warner into four parts, the New York Times commented “[Time Warner's] large shareholder base would make it extremely difficult for him to gain enough influence to force change," illustrating how large an impediment a widely dispersed shareholder base is to the market for corporate control.

There are two related justifications for why a widely dispersed shareholder base may influence control contests. First, as the number of shareholders grows, the influence of each shareholder on the outcome of a control contest falls and shareholders are more likely to freeride (Grossman and Hart, 1980). Second, as the shareholder base of the firm becomes more dispersed, the dollar value of each shareholder's stake falls. If there are fixed costs associated with being active, then more shareholders will be inactive in a widely held firm. ${ }^{1,2}$

Grossman and Hart (1980) show that when shareholders are atomistic a takeover bid can only succeed if the bid price is equal to the post-takeover share value (otherwise shareholders are better off not tendering). ${ }^{3}$ When the number of shareholders is finite, bids that are below the post-takeover share value may still be successful (Bagnoli and Lipman, 1988 and Holmström and Nalebuff, 1992). Essentially, when ownership by investors is no longer infinitesimal there is a probability that target shareholders perceive their tendering decision to be pivotal to the success of the tender offer and they thereby internalize part of the cost of them not tendering. As the ownership by each shareholder increases the likelihood that each shareholder is pivotal increases and the free-rider problem becomes less severe.

\footnotetext{
${ }^{1}$ Decision making is inherently costly and in the case of a tender offer shareholders have to evaluate the bidder's offer. Additionally, tendering shares involves an opportunity cost of time.

${ }^{2}$ The difference between the two justifications is that free-riding involves the active choice of not tendering; the alternative is that shareholders are inactive because of attention costs or the cost of acquiring information.

${ }^{3}$ In the atomistic shareholder setting, in the absence of a toehold (Shleifer and Vishny, 1986) or the possibility to dilute non-tendering shareholders ex-post (Grossman and Hart, 1980b), the profit of the takeover will not cover the bidder's cost of launching the bid and the takeover will not take place.
} 
The finite shareholder models generate several empirical predictions with respect to the degree of free-riding. Firstly, the larger the free-rider problem, the larger is the bid premium. The intuition for this is that as the free-rider problem is aggravated the bidder has to offer a higher price to make the pivotal shareholder indifferent between tendering and abstaining. Secondly, since bidder returns in a takeover are decreasing in the degree of freeriding, the more passive the shareholder base is the less likely it is that the firm receives a bid.

These two predictions are also consistent with shareholders being inactive. First, the lower the dollar value of the shareholders' stake, the higher the bid premium must be to induce shareholders to be active. Second, a higher bid premium lowers profits to the bidder and therefore reduces the likelihood that a takeover will take place.

This paper investigates the impact of shareholder passiveness (due either to freeriding or to inaction) on the market for corporate control. We measure the passiveness of the firm's shareholders as the fraction of shares outstanding owned by the average noninstitutional shareholder. We find that companies with more passive shareholders (lower average ownership per shareholder) are less likely to be takeover targets. A one standard deviation increase in passiveness results in a $0.37 \%$ decrease in the likelihood of observing a bid (or $8.89 \%$ relative to the unconditional mean). ${ }^{4}$ For firms that are in play, increasing the passiveness by one standard deviation decreases the likelihood of completion by $5.79 \%$ (which corresponds to a $16.14 \%$ increase in non-completion risk) and increases the takeover premium by $2.23 \%$ (or $18.01 \%$ relative to the mean). These findings suggest that a passive

\footnotetext{
${ }^{4}$ Among others, Hasbrouck (1985), Morck, Shleifer, and Vishny (1988, 1989), Mikkelson and Partch (1989), Ambrose and Megginson (1992), Song and Walkling (1993), Shivdasani (1993), and Comment and Schwert (1995) consider the characteristics of target firms.
} 
shareholder base is an impediment to changes of corporate control and hence acts as a takeover defense. ${ }^{5}$

The demonstrated relation between passiveness and the market for corporate control implies that the possibility of affecting passiveness is valuable to managers. There are a number of tools available to managers to alter the passiveness of the shareholder base. We show that shareholder passiveness can be significantly increased by undertaking a stock split or seasoned equity offering, while repurchases and reverse splits reduce passiveness. ${ }^{6}$ Thus, the firm's managers can use corporate decisions to influence the firm's passiveness and affect the likelihood and outcome of a takeover.

To investigate whether a passive shareholder base is a substitute for other takeover defenses, we consider the introduction of anti-takeover legislation in Delaware in the 1990s as a natural experiment. This legislation validated the use of poison pills in conjunction with staggered boards, thereby increasing the difficulty of a successful takeover (Subramanian, 2004). We utilize a differences-in-differences approach that accounts for the endogenous nature of firms' choices for the passiveness of the shareholder base and corporate governance.

Consistent with a passive shareholder base as acting as a substitute for other takeover defenses, we find that the ratification of the use of poison pills in conjunction with staggered boards leads to a reduction in the passiveness of the shareholder base by $10.5 \%$. Furthermore, this reduction is more pronounced in firms that had a smaller number of other anti-takeover provisions.

\footnotetext{
${ }^{5}$ There is evidence that other takeover defenses, like poison pills, result in higher takeover premiums (Comment and Schwert, 1995, Heron and Lie, 2006) and reduce the likelihood that a takeover will take place (Field and Karpoff, 2002). Our results are consistent with their findings on the impact of anti-takeover measures on the M\&A characteristics.

${ }^{6}$ Our results corroborate earlier findings of Mukherji, Kim, and Walker (1997) for stock splits and Bodnaruk and Östberg (2011) for repurchases.
} 
The prior literature has examined the relation between ownership structure and the market for corporate control by considering block, insider, or institutional ownership (e.g., Morck, Shleifer, and Vishny, 1988, McConnell and Servaes, 1990, Black, 1990). The presence of a blockholder may influence the degree of free-riding and passiveness. First, a large blockholder is likely to perceive his tendering decision to be pivotal and if his stake is sufficiently large then the free-rider problem is overcome. Additionally, a large blockholding by an investor may preclude the shareholder base from being passive. ${ }^{7}$

We demonstrate that passiveness is distinct from block ownership. ${ }^{8}$ Firstly, even though block ownership and passiveness are negatively related, the correlation between these two measures is a modest -0.17 . Secondly, we show that there is a lot of variability in shareholder passiveness controlling for block ownership. For example, $44.80 \%$ of firms with above median block ownership also have above median passiveness. Thirdly, we find that in $39.88 \%$ of all companies block ownership is below $25 \%$, indicating that in a large number of companies shareholder passiveness is still likely to be an issue. ${ }^{9}$ However, as expected, our regression results indicate that passiveness affects the market for corporate control most when block ownership is relatively low (below $25 \%$ ).

An advantage with our measure, the fraction of outstanding shares per shareholder, over variables like block ownership is that it has a clear relation to managerial entrenchment. When the stake per shareholder falls, shareholders are more passive and status quo is more likely to be preserved, and therefore managers are more entrenched. However, the relation

\footnotetext{
${ }^{7}$ Ferguson (1994) argues that in a setting in which there is competition among bidders, blockholdings by investors may not preclude free-riding. The reason is that the cost of not tendering is lower since competition implies that there will be future possibilities to tender.

${ }^{8}$ We also show that passiveness is distinct from insider ownership, institutional ownership, and corporate governance, but in the interest of brevity this analysis can be found in Appendix 2.

${ }^{9}$ In fact, $15.70 \%$ of our sample firms do not have block, insider, or institutional ownership above $25 \%$.
} 
between managerial entrenchment and block ownership is less clear since the block owner may or may not be aligned with management. In fact, Holderness (2009) shows that about $40 \%$ of block owners in U.S. firms do not have board representation. ${ }^{10}$

The contribution of this paper is threefold. First, we contribute to the literature on ownership structure by introducing a theoretically motivated measure of the degree of passiveness and verifying that this measure exhibits significant variation that is not captured by existing ownership measures. Second, once we have established the validity of our measure, we show that the degree of passiveness is a significant factor in the market for corporate control and a passive shareholder base is a substitute for other takeover defenses. Third, in a recent paper, Baker, Coval, and Stein (2007) argue that inertial behavior of target shareholders improves the terms for the acquiring firms in stock-for-stock mergers. Even though we share the conclusion that investor inertia / passiveness influences corporate policies we focus on different aspects of the market for corporate control.

We proceed as follows. Section 2 presents our hypotheses. Section 3 describes our data and our measure of passiveness. Section 4 investigates the role of passiveness in takeover contests. Section 5 shows how firm managers can affect passiveness through corporate events. Section 6 shows how firm passiveness responds to changes in takeover regulation. Section 7 considers various robustness issues. Section 8 concludes.

\footnotetext{
${ }^{10}$ Another potential measure of the free-rider problem is insider ownership. Even though managerial entrenchment is increasing in insider ownership, the agency problem vis-à-vis minority shareholders is also affected when insider ownership increases as a larger insider stake aligns the manager with minority interests (see Morck, Shleifer, and Visny, 1988). So any cross-sectional relation between insider ownership and the market for corporate control could either be due to differences in the free-rider problem or due to differences in the agency problem between insiders and minority shareholders.
} 


\section{Hypotheses development}

By relaxing the assumption of Grossman and Hart (1980) that there is a continuum of investors, Bagnoli and Lipman (1988), Holmstöm and Nalebuff (1992), and Ferguson (1994) allow for comparative statics with respect to the degree of the free-rider problem. When the ownership per investor decreases, the likelihood that an investor becomes pivotal falls and the free-rider problem is aggravated. As a consequence, the bid price increases in the takeover and the raider's surplus decreases. This leads to our first hypothesis:

Hypothesis 1: Firms that have more passive shareholders receive higher bid prices.

An increase in passiveness leads to a lower surplus to the raider since shareholders view their tendering as less pivotal. As a result, they internalize less of the effect of their tendering decision on the outcome of the takeover. Additionally, if there is a cost associated with launching a takeover bid, then all other things being equal we should observe fewer bids for firms with more passive shareholders, since the surplus of the raider has to compensate for the cost of undertaking the bid.

Hypothesis 2: Firms with more passive shareholders are less likely to receive takeover bids.

The increase in shareholder inactivity when the average ownership per shareholder falls also justifies hypotheses 1 and $2 .{ }^{11}$ In fact, these predictions can be justified by any model that generates an upward sloping supply curve of shares (e.g. Stulz 1988, Burkart,

\footnotetext{
${ }^{11}$ Separating the free-rider problem from shareholder inactivity is challenging, since the two are observationally equivalent along the dimensions considered in this paper.
} 
Gromb, and Pannunzi, 1998), as long as a more passive shareholder base implies that fewer shares are tendered.

Field and Karpoff (2002) document that the presence of a poison pill reduces the likelihood that a takeover will be completed. If a passive shareholder base is a takeover defense, then we would expect a lower likelihood of completion when the shareholder base is passive.

Hypothesis 3: In a takeover contest, a more passive shareholder base implies a lower likelihood of deal completion.

Stulz (1988) argues that there is an optimal level of takeover protection. A too low level of takeover protection results in an inefficiently low (from the shareholder's perspective) bid price in a takeover, while a too high level of protection results in an inefficiently low likelihood of receiving a takeover bid.

If so, the implementation of more stringent anti-takeover legislation should result in firms reducing other forms of takeover protection. The takeover protection of all firms incorporated in Delaware was unexpectedly increased in 1995 when the use of poison pills in conjunction with staggered boards was allowed. Firms should respond to this legislation by reducing other forms of takeover protection in order to return to the optimal level. In effect, after the increase in takeover protection, the management has fewer incentives to pursue costly activities, such as advertising (Grullon, Kanatas, and Weston, 2004), that have been shown to increase the retail shareholder base. Additionally, we document that managers can reduce passiveness through undertaking a reverse stock split or a share repurchase. This gives our final hypothesis: 
Hypothesis 4: The passiveness of the shareholder base falls following an increase in anti-takeover regulation.

We now proceed to describe our data.

\section{Data and descriptive statistics}

In this section, we define and provide descriptive statistics on our measure of passiveness. We then relate passiveness to other measures of the free-rider problem and corporate governance.

\subsection{Measuring passiveness}

There is an extensive literature that documents that institutional investors are active monitors (e.g., Gillan and Starks, 2007). Additionally, Baker et al. (2007) show that institutional investor exhibit little inertia relative to retail investors. We, therefore, exclude institutional ownership from our measure of passiveness. We define Passiveness as

$$
\text { Passiveness }=-\log \left(\frac{1-I 0}{\text { common shareholders }- \text { institutional investors }}\right)
$$

where IO (institutional ownership) is the fraction of outstanding shares owned by institutions, common shareholders is the number of common shareholders of record, and institutional investors is the number of institutional investors. ${ }^{12,13} \mathrm{We}$ use the logarithm to control for

\footnotetext{
${ }^{12}$ Both the number of common shareholders and the number of institutional investors are measured in thousands.

${ }^{13}$ Strictly speaking, we measure the characteristics of the average rather than the marginal shareholder. So an implicit assumption of our empirical analysis is that the average shareholder is a reasonable proxy for the marginal shareholder.
} 
skewness and multiply the expression by (-1) to ensure that our measure is increasing in passiveness. We use Compustat item 100, "number of common shareholders of record," to measure the number of common shareholders; institutional ownership is from Spectrum 13f. ${ }^{14}$ Since the number of common shareholders of record is available on a yearly frequency, our measure of passiveness is measured at the end of the year and is valid for the next year.

We calculate the "derived equity stake" of non-institutional shareholders of record as the ratio of fraction of shares outstanding owned by non-institutional shareholders divided by the number of non-institutional shareholders. We then calculate its dollar value by multiplying it by the company market capitalization at the end of year.

$$
\$ \text { Value of Derived Equity Stake }=\frac{\text { Market Capitalization } \times(1-I 0)}{\text { common shareholders }- \text { institutional investors }}
$$

The mean (median) derived equity stake (Table 1$)$ is $0.025(0.017)$ of a percentage point. The average (median) dollar value of the derived equity stake is $138,140(31,360)$ US dollars. These numbers are large because Compustat item 100 understates the number of shareholders. We evaluate the impact of this in Section 3.2. As expected, the average retail ownership is significantly lower than that of institutional owners. The average (median) institutional investor holds 0.898 (0.576) of a percentage point of outstanding equity. The mean (median) dollar value of an institutional position is $4.70(1.91) \mathrm{mln}$.

Our measure of passiveness does not exclude block ownership or insider ownership, which we derive from Compact Disclosure, since they are not mutually exclusive from institutional ownership (Holderness, 2009). For example, if an insider owns a stake that is

\footnotetext{
${ }^{14}$ The average passiveness of Time Warner (mentioned in the introductory paragraph) over our sample period was 5.30, which corresponds to an average stake of non-institutional investors of $4.99 \times 10^{-4}$ of a percent. That puts the passiveness of Time Warner among the top 5\% of firms.
} 
larger than 5\%, then that stake will be included in both insider ownership and block ownership in Compact Disclosure. This implies that block ownership, insider ownership, and institutional ownership together often exceed the total amount of shares outstanding. In fact this is true for $40.67 \%$ of firms in our sample. In our analysis we separately consider situations when block or insider or institutional ownership is above or below $25 \%$. Additionally, we use block, institutional, and insider ownership as control variables.

Table 1 presents descriptive statistics on passiveness and inside, block, and institutional ownership. The average (median) passiveness is $0.96(0.77)$. There is also considerable variability in passiveness across firms in our sample; the standard deviation is 1.93. The average (median) block ownership is $36.66 \%(33.18 \%)$ of shares outstanding. This number is consistent with Holderness (2009), who reports that in his random sample of $10 \%$ of the firms available in Compact Disclosure, block ownership is on average 39\%. At the same time, block ownership is below $25 \%$ in $39.88 \%$ of all companies, which suggests that passiveness may be a consideration in a takeover contest for a large number of firms.

\subsection{Passiveness and holdings through brokerage accounts}

In the previous section, we found that the median investor stake in a firm is 31,360 US dollars (according to the derived equity stake). This number seems large; an important reason why we overestimate the value of investor stakes is that all shareholders that hold stock through a financial intermediary are counted as one shareholder. This implies that the denominators in equation (1) and (2) are underestimated. However, there is no reason to suspect that the underestimation affects certain stocks or groups of stocks in a different way. 
Nonetheless, to examine the effect of the understatement in the number of shareholders on passiveness we calculate Passiveness and the Dollar Value of Derived Equity Stake using individual investor level data from Sweden. Since the Swedish data possesses detailed information about investor stockholdings irrespective of whether the stock is held directly or through an intermediary, it allows us to compare passiveness calculated only through direct holdings (as in the U.S.) to passiveness calculated through the actual investor positions.

The data comes from Värdepapperscentralen (VPC), which records stock ownership at the investor level (each investor is identified by an anonymized equivalent to the social security number). The dataset also has information on investor type and whether the position is held directly or through a financial intermediary. ${ }^{15}$

Table 2 presents the results from the Swedish data. We consider all stocks traded on the Stockholm Stock Exchange in $2000 .{ }^{16}$ In Sweden, in the average firm $38.9 \%$ of investors own the stock directly and $61.1 \%$ of investors hold the stock through an intermediary.

We compare the dollar value of the actual positions of all non-institutional investors (direct holdings and holdings through an intermediary) to the dollar value of positions that are held directly. The mean (median) dollar value of the actual position of all investors is 24,245 (444) US dollars while the mean (median) dollar value of actual directly held positions is 28,650 (400) US dollars. These numbers suggest that directly held stakes are very similar to the stakes held through intermediaries. The magnitude of these numbers is also comparable to those found by Barber and Odean (2000), who consider data from a U.S. brokerage firm.

\footnotetext{
${ }^{15}$ For a closer description of the dataset, see Gianetti and Simonov (2006) or Massa and Simonov (2006).

${ }^{16}$ All of the values reported in Table 2 are in US dollars.
} 
We then calculate the Dollar Value of Derived Equity Stake (equation 2) using directly held positions for the Swedish sample; the mean (median) is $181,316(33,879)$ US dollars. So, only considering investors that hold the stock directly implies that the calculated dollar value of stakes in Sweden is similar to those calculated for the U.S. (mean 138,140, median 31,360 US dollars).

Finally, to examine the impact of having only direct holdings on the measurement of passiveness, we calculate two measures of passiveness (Equation (1)) for Sweden, using the actual position values of investors (Actual Passiveness) and derived equity stakes of direct stock owners (Passiveness). As expected, the latter is significantly smaller; however, the correlation between these two variables is in excess of $95 \%$. Additionally, the Adj. $\mathrm{R}^{2}$ of the regression of Actual Passiveness on Passiveness is $86.5 \%$. All of the above suggests that the measure of passiveness estimated from derived equity stakes of non-institutional investors is a good proxy for passiveness.

\subsection{Passiveness, other measures of ownership, and corporate governance}

We now proceed to relate passiveness to other measures of the free-rider problem and corporate governance. The correlation between block ownership and passiveness is -0.17 . The negative relation is to be expected, since large block holdings raise the average ownership per shareholder. However, there is a significant amount of variation in passiveness that is not due to variation in block ownership. To demonstrate this, we sort companies into two groups by block ownership and separately sort them into two groups by passiveness. We then calculate the frequencies of firms falling in corresponding block ownership / passiveness groups. If block ownership fully determines passiveness, then all firms that have high block 
ownership will also have low passiveness and vice versa (i.e., no firms will have high block ownership and high passiveness). Independence between block ownership and passiveness implies that each of the four block ownership and passiveness groups should contain $25 \%$ of all firms.

We find that the distribution of firms across block ownership / passiveness groups is very even: $22.40 \%$ of our sample firms have higher than median block ownership and higher than median passiveness. That implies that $27.60 \%$ of our sample firms have high block ownership and low passiveness.

To further corroborate the hypothesis that passiveness and block ownership are distinct, we find that companies with similar block ownership are often on opposite ends of the distribution in terms of passiveness. For example, Allos Therapeutics (cusip 019777) and Ariad Pharmaceuticals (cusip 04033A) are both pharmaceutical companies (SIC2=28) that as of the end of 2006 had a similar market capitalization $(331 \mathrm{mln}$ vs. $336 \mathrm{mln})$ and block ownership (21.90\% vs $22.79 \%$ ). Allos's passiveness was -3.40 , which places the company in the bottom $25 \%$ of passiveness, whereas Ariad's passiveness is 4.42 , which puts the company among the top $25 \%$ in terms of passiveness.

In a similar way we relate passiveness to insider ownership, institutional ownership, and corporate governance as measured by the G-index of Gompers, Ishii, and Metrick (2003). ${ }^{17}$ The results are qualitatively similar to those of passiveness and block ownership. In the interest of brevity we report the results in Appendix 2.

To provide additional evidence that shareholder passiveness is a distinct company characteristic, we run a set of regressions with passiveness as the dependent variable and

\footnotetext{
${ }^{17}$ An insider that owns more than $5 \%$ of outstanding voting stock is also classified as a blockholder and therefore to some extent controlled for when we consider block ownership.
} 
block ownership, insider ownership, institutional ownership, corporate governance, and company size as explanatory variables. Even though all of the above variables turn out to be statistically significant in the regression their explanatory power - individually and combined - appears to be rather low. Block ownership alone explains explain $3.15 \%$ of passiveness, insider ownership explains 7.08\%, institutional ownership explains 19.14\%, G-index explains 5.09\%, and size explains $32.45 \%$. Inclusion of all five of them in the regression results in an $\mathrm{R}^{2}$ of $36.19 \%$.

To summarize, while passiveness is related to the previously used measures of freeriding and company corporate governance defenses, there is a lot of variation in passiveness that is not explained either by any of these variables single-handedly or by all of them combined. Thus, the evidence presented here suggests that passiveness is a distinct company characteristic. $^{18}$

Additionally, in our analysis we control for the following company characteristics: book-to-market, age, total payout, price-to-earnings, debt-to-equity, operating income, past year return, stock volatility, stock liquidity, industry affiliation, and industry concentration. A detailed description of the variables is provided in Appendix 1. All accounting and performance variables are derived from the CRSP-Compustat Merged database (CCM). Descriptive statistics of the control variables are provided in Table 1.

\section{Shareholder passiveness and the market for corporate control}

\footnotetext{
${ }^{18}$ We have also considered the relation between passiveness and industry. In general, industries in which firms have other firms as customers, like chemical services or leather production, are characterized by low passiveness. Industries in which firms have individuals as customers, like retail firms and communications, are the most passive. The results can be found in Table R2.
} 
We start by relating passiveness of the shareholder base to the characteristics of mergers and acquisitions. Our source of data on merger activity is the Securities Data Corporation (SDC) M\&A database, from which we extract all merger transactions involving U.S. targets over the period of 1981-2007. To be included in the sample, we require the target firm to be listed and to report the number of common shareholders of record; additionally, it must be possible to match the target's CUSIP with CRSP. The resulting sample comprises 4,642 M\&A announcements. We complement this data with the data on block and insider ownership, which we derive from Compact Disclosure. Since it only covers the period from 1991 to 2006, this reduces number of observations in some of our tests.

We first investigate the relation between passiveness and the likelihood of receiving a takeover bid. We estimate a probit regression where the dependent variable takes a value of 1 if a company receives a takeover bid in the following year, 0 otherwise. The results are reported in Table 3. We find that shareholder passiveness is negatively and statistically significantly related to the likelihood of observing a bid. In our baseline specification (1), a one standard deviation increase in passiveness leads to a reduction of bid likelihood by $0.42 \%$ (or $10.12 \%$ relative to the sample mean).

Specification (2) introduces insider ownership and block ownership as controls. Accounting for these measures of ownership does not have a material effect on the impact of passiveness on the likelihood of receiving a bid. Now a one standard deviation increase in passiveness is associated with a $0.33 \%$ decrease in the likelihood of receiving a bid (or $10.28 \%$ relative to the sample mean). To put these numbers into perspective, a one standard deviation increase in institutional ownership increases the likelihood of receiving a bid by $0.62 \%$; for block ownership and insider ownership the corresponding increases are $0.04 \%$ and $0.09 \%$. 
To examine whether the effect of passiveness varies depending on the ownership structure of the firm, we introduce three dummy variables. The variables HighIO, HighBlock and HighInside take a value of 1 if institutional, block, or insider ownership are greater than $50 \%, 25 \%$, or $10 \%$, respectively. In specification (3), we interact passiveness with HighIO and its complement. As expected, we find that the impact of passiveness is larger when institutional ownership is low. A one standard deviation increase in passiveness reduces the likelihood of receiving a bid by $0.45 \%$ (or $13.88 \%$ relative to the mean) for firms with institutional ownership below 50\%, while for high institutional ownership firms it is not statistically significant.

In specification (4) we interact passiveness with HighBlock. Similar to the institutional ownership case, we find that for firms without significant block ownership the effect of passiveness is stronger. To further illustrate the point, specification (5) considers those firms for which we expect the effect of passiveness to be the greatest. We interact passiveness with a dummy variable that takes a value of 1 if HighIO, HighBlock, or HighInside equals 1 . This means that those firms that do not belong to this group have institutional ownership below 50\%, block ownership below 25\%, and insider ownership below $10 \%$. In our sample, $17.57 \%$ of firms satisfy these criteria. For these firms the effect of passiveness is substantially greater; a one standard deviation increase in passiveness leads to a decrease in the likelihood of receiving a bid of $0.82 \%$, compared to $0.22 \%$ for firms with concentrated ownership.

We proceed to investigate the relation between passiveness and the likelihood of deal completion. We estimate a probit regression where the dependent variable takes a value of 1 if the bid is ultimately successful, 0 otherwise. The results, reported in Table 4, show that 
firms with a passive shareholder base are less likely to be taken over upon receiving a bid. In our baseline specification, (1), the marginal effect of a one standard deviation increase in passiveness is a $5.71 \%$ reduction in the likelihood of completion of the deal, which corresponds to $16.15 \%$ increase in non-completion risk. Controlling for insider and block ownership (specification (2)) reduces the marginal impact of passiveness to $4.45 \%$. However, this is still large compared to the marginal impact of institutional ownership (2.77\%), block ownership (2.05\%), and insider ownership (1.83\%).

We then interact passiveness with our dummy variables HighIO, HighBlock, and HighInside. In specifications (3) to (5), we find weak evidence that the impact of passiveness is larger in the absence of concentrated ownership. In specification (6), we analyze the impact of the presence of a poison pill on deal completion. To do this we introduce a dummy variable, poison pill that takes the value of 1 if the firm has a poison pill and 0 otherwise. We interact the presence of a poison pill with passiveness and find that in the absence of a poison pill passiveness is negatively and statistically significantly related to deal completion, while the presence of a poison pill renders passiveness insignificant.

Finally, we turn our attention to the effect of shareholder passiveness on the takeover premium (Table 5). Our dependent variable is the four-factor adjusted return on the target's stock from 3 months before the bid announcement to 2 months after the deal announcement or resolution date, (i.e. $(-63$; $\min (+42$, resolution date) ) event window) (Schwert, 2000). We find that companies with more passive shareholders command higher premiums in takeovers. In specification (1), a one standard deviation increase in passiveness results in a $2.23 \%$ higher premium, which corresponds to an $18.1 \%$ increase relative to the mean. The result is consistent with Comment and Schwert (1995), who argue that takeover defenses shift 
bargaining power toward the target firm, which leads to a higher premium for the target shareholders. The magnitude of the relationship goes up to $4.48 \%$ after accounting for insider and block ownership (specification (2)). The economic impact of shareholder passiveness on the M\&A premium is comparable to the impact of institutional ownership (5.82\%), insider ownership (3.65\%), and block ownership (7.12\%).

In specifications (3) to (5), we consider the effect of concentrated ownership on the relation between passiveness and the takeover premium. For firms with highly concentrated ownership, the relation between passiveness and the takeover premium is marginal at best. However, for firms that do not have concentrated ownership, the positive relation between passiveness and the takeover premium is statistically and economically strong. For example, for firms with low block ownership (specification (4)), a one standard deviation increase in passiveness results in an $8.15 \%$ increase in the takeover premium. In specification (6), by interacting our dummy variable for the presence of a poison pill with the passiveness of the shareholder base, we can deduce whether the effect of a passive shareholder base is altered by a poison pill. For firms that have a poison pill the relation between passiveness and the takeover premium is insignificant, while the relation is almost unaltered for those firms that do not have poison pill. This indicates that a passive shareholder base is a substitute for a poison pill: when a poison pill is present the marginal effect of a passive shareholder base is minimal.

As an example of the importance of high shareholder passiveness for the outcome of a takeover contest, consider the hostile bid by Kollmorgen for Pacific Scientific in December 1997. Surrounding the announcement Pacific Scientific experienced a stock price increase of 67.91\%. Nonetheless, the shareholder base of Pacific Scientific was so diffuse that it 
managed to fend off the hostile bid. In fact, the passiveness of Pacific Scientific at the time of the bid was 2.51, which put it in the upper quartile in terms of passiveness. ${ }^{19}$

\section{Managing passiveness}

In the previous section we demonstrated that companies with higher shareholder passiveness are better able to fight off takeovers. Since passive shareholders are unlikely to tender their shares in M\&As, their votes are effectively controlled by the management in the spirit of Stulz (1988). The ability to affect passiveness should, therefore, be valuable to the management.

We now proceed to investigate the tools that managers have at their disposal to alter the degree of shareholder passiveness. Our non-exhaustive list of corporate decisions that might affect the number of non-institutional investors includes stock splits, reverse stock splits, seasoned equity offerings, and share repurchases. ${ }^{20}$ The data on splits, reverse splits, and SEOs comes from SDC. We derive information on share repurchases from CRSPCompustat Merged database.

To investigate the effect of corporate events on the shareholder passiveness, we estimate the following pooled panel regression,

$$
\begin{gathered}
\text { PAssiveness }_{i,(t, t+1)}=\beta_{\text {Split }} \times \text { Split }_{i, t}+\beta_{\text {Reverse Split } \times \text { ReverseSplit }_{i, t}+} \\
+\beta_{\text {Repurchase }} \times \text { Repurchase }_{i, t}+\beta_{S E O} \times S E O_{i, t}+X_{i, t}^{\prime} \Gamma+\epsilon_{i, t}
\end{gathered}
$$

\footnotetext{
${ }^{19}$ It was later acquired by Danaher.

${ }^{20}$ One notable corporate decision that has been documented to increase the number of shareholders is advertising expenditure (Grullon, Kanatas, and Weston, 2004). We exclude advertising expenditure since it would result in a tenfold decrease in sample size.
} 
where $\Delta \mathrm{Pass}_{\mathrm{i}(\mathrm{t}, \mathrm{t}+1)}$ is the difference in passiveness between year $\mathrm{t}$ and $\mathrm{t}+1$ of firm $\mathrm{i}$. In specifications (1) and (3), Split (Reverse Split, Rep, and SEO) is a dummy which equals 1 if a company undertook a stock split (reverse split, repurchase, or SEO) in year $\mathrm{t}$ and 0 otherwise. However, in specifications (2) and (4) we consider the size of the corporate decision (i.e., Split $\mathrm{i}_{\mathrm{i}, \mathrm{t}}$ refers to how large a split firm $\mathrm{i}$ did in year $\mathrm{t}$ ). In all of our specifications, $X$ is a set of company characteristics augmented by time and industry fixed effects. All of our explanatory variables are measured in year $\mathrm{t}$ and defined in Appendix 1. Standard errors are clustered at industry level.

We present our regression results in Table 6 . As expected, we find that undertaking a stock split or a seasoned equity offering results in an increase in passiveness. On the other hand, firms that undertake a reverse-split or a repurchase reduce shareholder passiveness. These findings mirror those of Mukherji, Kim, and Walker (1997) on stock splits and those of Bodnaruk and Östberg (2011) on repurchases. The results remain qualitatively unchanged if we consider the magnitude of corporate events instead of dummies and/or control for contemporaneous changes in other measures of ownership.

In terms of economic magnitudes, in specification (3) a typical firm undertaking a stock split increases its shareholder passiveness by 0.06 , which corresponds to $97.54 \%$ relative to the mean yearly change in passiveness for the entire sample of firms. Undertaking a reverse stock split on average reduces passiveness by -0.13 (or by $205.36 \%$ relative to the mean yearly change). Similarly, undertaking a repurchase reduces passiveness by -0.05 (or by $74.47 \%$ relative to sample mean). To summarize, management appear to have a range of effective tools at their disposal that could be utilized to affect the passiveness of shareholder base. 


\section{Exogenous shock to anti-takeover protection and passiveness of shareholder base}

\subsection{Empirical strategy}

Our central tenet is that a passive shareholder base acts as a takeover defense and therefore is a substitute for other takeover defenses. To test this, we consider the change in Delaware's takeover law that provided an increased level of takeover protection. Those firms affected by the regulatory change should respond by reducing other takeover defenses, so as to return to the optimal level of takeover protection. ${ }^{21}$ Hence, we expect firms incorporated in Delaware to reduce the size of their shareholder base in response to this legal change relative to non-Delaware firms.

The challenge to investigating this statement in our context is unobserved firm heterogeneity and the endogenous nature of the passiveness of a firm's shareholder base. To address this issue, we use differences-in-differences methodology.

The basic regression model to estimate the differences-in-differences effect of this anti-takeover law is:

$$
\text { Passiveness }_{i, t}=\beta_{\text {Delaware }} \times \text { Delaware }_{i} \times \text { After } 1995_{i, t}+X_{i, t}^{\prime} \Gamma+\epsilon_{i, t}(4)
$$

where Delaware $_{i}$ is an indicator variable that is 1 if a firm is incorporated in Delaware, After $1995_{i, t}$ is an indicator variable that is 1 if an observation is after $1995, X$ is a set of company specific characteristics augmented by state, industry, and time fixed effects, and is $\epsilon_{i, t}$ an error term.

\footnotetext{
${ }^{21}$ Stulz (1988) argues that when choosing the optimal takeover protection, firms trade off the probability of receiving a takeover bid against the price of the bid.
} 
This regression implements the differences-in-differences methodology for multiple comparison groups, where state fixed effects account for fixed differences between firms in the passing and non-passing states of the anti-takeover law, and time fixed effects control for aggregate fluctuations. Under this specification, the coefficient estimate on the interactive term Delaware $e_{i} \times$ After $1995_{i, t}$ measures the differences-in-differences effect of the antitakeover laws on the passiveness of shareholder base. We also control for a number of variables used in the previous section. Standard errors are clustered at the state and time level to account for the serial correlation concerns associated with a differences-in-differences estimation (Bertrand, Duflo, and Mullainathan, 2004).

\subsection{Regression results}

In Table 7 we report the results on the effect of changes in takeover law in Delaware on the passiveness of shareholder base. Specification (1) shows that the parameter estimate on the interaction between the post-1995 and the Delaware indicator variables is significantly negative. That is, firms in Delaware reduced the passiveness of their shareholder base by $22.13 \%$ in response to Delaware's change in takeover laws, after accounting for systematic differences between Delaware and non-Delaware firms, and economy-wide effects. This result is consistent with the optimizing behavior of an entrenched manager: once the threat of a takeover is reduced by legal change, the manager responds by reducing the level of takeover protection by allowing the shareholder base to become less passive. Accounting for insider and block ownership - specification (2) - reduces the magnitude of the abnormal drop in passiveness to $10.5 \%$, which is still economically and statistically significant. 
Specification (3) presents the results of a differences-in-differences-in-differences (DDD) specification by separating firms with and without poison pills. Our conjecture is that firms with existing takeover defenses will respond less to a legal change in takeover laws. Consistent with this hypothesis, we find that firms without poison pills incorporated in Delaware decreased the passiveness of their shareholder base after 1995 by $21.34 \%$, while the passiveness of the shareholder base for Delaware firms with poison pills remained unchanged after accounting for the state-specific (Delaware vs. non-Delaware firms), timespecific (pre- and post-1995 years), and firm-level takeover defense (firms with and without poison pills) differences.

In specification (4), we repeat the differences-in-differences-in-differences (DDD) estimation using governance index G-index instead of the poison pill indicator. Since firms with a large governance index measure managerial entrenchment with existing takeover defenses, we expect these firms to be less responsive to Delaware's legal change. Consistent with this hypothesis, we find that the parameter estimate of the triple-interaction term (indicators of Delaware, post-1995, and G-index) is significantly positive. In other words, the passiveness of the shareholder base for Delaware incorporated firms decreased after 1995 primarily for the firms with low levels of anti-takeover defenses, whereas there has been little change for companies with high values of G-index.

To sum up, these results support the view that corporate governance (the disciplinary threat of takeover) impacts firms' choices concerning the passiveness of their shareholder base, and that the passiveness of the shareholder base is used as a takeover defense mechanism by entrenched managers. 


\section{Robustness}

We have shown that our measure of passiveness is related to the market for corporate control. In this section, we document that passive shareholders are also less active in other dimensions. First, we consider the retail trading volume of passive firms and find that passive firms have a lower retail trading volume. Second, we expect firms with passive shareholders to have lower values of Tobin's Q, since their shareholders are more likely to free-ride in all governance issues, not only when it comes to tendering shares in control contests.

\subsection{Passiveness and retail trading}

We relate trading activity to the passiveness of the shareholder base in Table 8 . We consider three measures aimed at capturing the trading activities of retail investors: the ratio of the number of retail trades to the number of total trades executed by all investors (Specifications (1) and (2)), the ratio of the number of shares traded by retail investors to the number of total shares traded by all investors (Specifications (3) and (4)), and the ratio of the dollar value of shares traded by retail investors to the total dollar value of shares traded by all investors (Specifications (5) and (6)). We classify retail investors' trades as those trades with less than 500 shares, using the convention of small trades adopted in Security and Exchange Commission's Rule 11Ac1-5 (i.e., Dash-5). ${ }^{22}$ Using the Trades and Quotes (TAQ) database produced by the New York Stock Exchange (NYSE), we first compute these ratios stock by stock on a daily basis, and then average these ratios with appropriate horizons. The data covers the period 1992 to 2006.

\footnotetext{
${ }^{22}$ We recognize that this classification has its limitations. In a number of unreported robustness checks, we further classify "small retail trades" based on the alternative classification algorithm developed in Lee and Radhakrishna (2000) and recently adopted in Malmendier and Shanthikumar (2007), Barber, Odean, and Zhu (2009), and Hvidkjaer (2009), among others. The results are qualitatively similar.
} 
We use the set of standard control variables used in Chordia, Huh, and Subrahmanyam (2007), including institutional ownership, size, book-to-market ratio, past one-year stock return, return volatility, stock liquidity, and industry fixed effects. We also control for year fixed effects in all of our regressions to take into account potential timeseries trends in our small trade measures. ${ }^{23}$

Panel A of Table 8 presents the results on the relation between average daily retail trading activity and passiveness. The dependent variables are daily averages of our small trades measures computed over the subsequent year. Consistent with our conjecture, a more passive shareholder base is associated with less retail trading; the effect is also economically and statistically significant. A one standard deviation increase in passiveness is associated with a decrease in retail trading activity of between $3.2 \%$ and $7.2 \%$ relative to the unconditional mean.

Panel $\mathrm{B}$ focuses on the trading activity of retail investors during the earnings announcement period. We view the results reported in Panel B as a set of conditional results in which the conditioning variable is the news of the earnings announcement. To the extent that earnings announcements constitute important firm-initiated news, earnings announcements provide incentives for market participants - including retail investors - to trade (see Chordia et. al, 2007). Therefore, focusing on the earnings announcement period trading activities of retail investors provides us with additional ability to delineate the market participation of retail investors. The dependent variables in these regressions are the daily averages of our small trades measures computed over the 3-day event window starting on the

\footnotetext{
${ }^{23}$ For example, there is an increasing tendency for sophisticated institutional investors to break up trades into smaller pieces to attenuate price impact (i.e., the so-called "order slicing" practice) after 2002. In addition, to include fixed effects in our regressions, we have also verified that our results are robust if we restrict our sample to before 2002 .
} 
day of the earnings announcement and ending two days after. The results are in line with the unconditional tests reported in Panel A. A one standard deviation increase in passiveness is associated with a decrease in retail trading activity of between $2.6 \%$ and $7.7 \%$ relative to the unconditional mean. To summarize, shareholder passiveness appears to have a significant impact on the retail trading activity.

\subsection{Tobin's $Q$ of passive firms}

A passive shareholder base implies that the status quo is much more likely to be maintained and that the manager is effectively entrenched. To verify this, we relate passiveness to Tobin's Q (Table 9). As expected, we find a negative and statistically significant relation between passiveness and Tobin's Q. In terms of economic impact (Specification (2)), a one standard deviation increase in passiveness results in a reduction in Tobin's Q of 0.10. In specifications (3) through (5), we consider the effect of concentrated ownership on the relation between passiveness and Tobin's Q. As before, passiveness matters most in firms with less concentrated ownership. For firms with highly concentrated ownership, the relation between passiveness and Tobin's Q is never statistically significant.

\section{Conclusions}

In June 2006, Kirk Kerkorian owned 9.9\% of General Motors (GM) through his holding company Tracinda. Kerkorian and several other shareholders were vocal about their displeasure with GM's board and management. However, Business Week commented that "Unless he and his man-at-arms (and former GM director) Jerome York can win over GM's 
historically passive shareholder base, ..., it will be tough to gain control by arguing that Wagoner isn't doing anything right. ${ }^{24}$

This example illustrates that in practice a passive shareholder base may be a significant impediment to changes in control even in the presence of blockholders. ${ }^{25}$ In this paper, we examine the effect of passiveness on the market for corporate control. To do this we consider the passiveness of the shareholder base (low ownership per shareholder). We find that firms that have a passive shareholder base are less likely to receive takeover bids and are less likely to be taken over. And if they are taken over, firms with a more passive shareholder base command a higher premium. In terms of economic magnitude, a one standard deviation increase in the passiveness of the shareholder base decreases the likelihood of deal completion by $5.79 \%$, which corresponds to a $16.14 \%$ increase in the noncompletion risk. Similarly, a one standard deviation increase in the passiveness of the shareholder base leads to a $2.23 \%$ increase in the takeover premium.

In order to address the issue of endogeneity, we investigate the impact of an exogenous increase in anti-takeover legislation in Delaware in the mid-1990s as a natural experiment. When Delaware ratified the use of a staggered board in conjunction with a poison pill, the passiveness of firms incorporated in Delaware fell.

Taken together our results indicate that shareholder passiveness affects the outcomes, of corporate control contests and is a substitute for other takeover defense mechanisms.

\footnotetext{
24 “GM's Wagoner gets ready to fight back," Business Week, October 23, 2006

${ }^{25}$ Even with significant block ownership General Motors was in the top $1 \%$ of firms in terms of passiveness.
} 


\section{References}

Ambrose, Brent W., and William L. Megginson, 1992, The role of asset structure, and takeover defenses in determining acquisition likelihood, Journal of Financial and Quantitative Analysis 27, 575-589.

Bagnoli, Mark, and Barton L. Lipman, 1988, Successful Takeovers without Exclusion. Review of Financial Studies 1, 89-110.

Barber, Brad M., and Terrance Odean, 2000, Trading is hazardous to your wealth: The common stock investment performance of individual investors, The Journal of Finance 55, 773-806.

Barber, Brad M., Terrance Odean and Ning Zhu, 2009, Do retail trades move markets?, Review of Financial Studies 22, 151-186.

Bertrand, Marianne, Esther Duflo, and Sendhil Mullainathan, 2004, How Much Should We Trust Differences-in-Differences Estimates?, Quarterly Journal of Economics 119, 249-275.

Betton, Sandra, B. Espen Eckbo, and Karin S. Thorburn, 2008, Corporate Takeovers, Handbook of Corporate Finance: Empirical Corporate Finance 2, 291-430.

Black, Bernard S., 1990, Shareholder Passivity Reexamined, The Michigan Law Review 89, 3: 520608.

Bodnaruk, Andriy and Per Östberg, 2011, The shareholder base and payout policy, Working paper.

Bradley, Michael, Anand Desai, and E. Han Kim, 1983, The rationale behind interfirm tender offers: Information of synergy?, Journal of Financial Economics 11, 183-206.

Burkart, Mike, Denis Gromb, and Fausto Pannunzi, 1998, Why higher takeover premia protect minority shareholders, Journal of Political Economy 106, 172-204.

Bushee, Brian J., and Gregory S. Miller, 2008, Investor relations, firm visibility, and investor following, Working paper series, University of Pennsylvania.

Chordia, Tarun, Sahn-Wook Huh, and Avanidhar Subrahmanyam, 2007, The cross-section of expected trading activity, Review of Financial Studies 20, 709-740.

Comment, Robert, and G. William Schwert, 1995, Poison or Placebo? Evidence on the Deterrence and Wealth Effects of Modern Antitakeover Measures, Journal of Financial Economics 39, $3-43$.

Ferguson, Michael F., 1994, Ownership structure competition and the free-rider problem in tender offers, Journal of Law Economics and Organization 10, 35-62.

Field, Laura C., and Jonathan M. Karpoff, 2002, Takeover Defenses of IPO Firms, Journal of Finance 57, 1857-1889. 
Gillan, Stuart L., and Laura T. Starks, 2007, The Evolution of Shareholder Activism in the United States, Journal of Applied Corporate Finance 19, 55-73.

Giannetti, Mariassunta and Andrei Simonov, 2006, Which investors fear expropriation? Evidence from investors' portfolio choices, The Journal of Finance 61, 1507-1547.

Gompers, Paul, Joy Ishii, and Andrew Metrick, 2003, Corporate Governance and Equity Prices, Quarterly Journal of Economics 118, 107-155.

Grossman, Sanford J., and Oliver D. Hart, 1980, Takeover bids, the free-rider problem, and the theory of the corporation, Bell Journal of Economics 11, 42-64.

Grossman, Sanford J., and Oliver D. Hart, 1980b, Disclosure laws and takeover bids, The Journal of Finance 35, 323-334.

Grullon, Grullon, George Kanatas and James P. Weston, 2004, Advertising, Breadth of Ownership, and Liquidity, The Review of Financial Studies 17, 439-461.

Hasbrouck, Joel, 1985, The characteristics of takeover targets, The Journal of Banking and Finance 9, 351-362.

Heron, Randall, A., and Erik Lie, 2006, On the Use of Poison Pills and Defensive Payouts by Takeover Targets, Journal of Business 79, 1783-1807.

Holderness, Clifford G., 2009, The Myth of Diffuse Ownership in the United States, Review of Financial Studies 22, 1377-1408.

Holmström, Bengt, and Barry Nalebuff, 1992, To the Raider Goes the Surplus: A Re-examination of the Free-rider Problem, Journal of Economics and Management Strategy 1, 37-62.

Huang, Yen-Sheng, and Ralph A. Walkling, 1987, Target abnormal returns associated with acquisition announcements: Payment, acquisition, and managerial resistance, Journal of Financial Economics 19, 127-168.

Hvidkjaer, Soeren, 2008, Small trades and the cross-section of stock returns, Review of Financial Studies 21, 1123-1151.

Lee, Charles M.C., and Balkrishna Radhakrishna, 2000, Inferring investor behavior: Evidence from TORQ data, Journal of Financial Markets 3, 83-111.

Malmendier, Ulrike and Devin Shanthikumar, 2007, Are small investors naive about incentives?, Journal of Financial Economics 85, 457-489.

Massa, Massimo, and Andrei Simonov, 2006, Hedging, familiarity and portfolio choice 19, 633-685.

McConnell, John J., and Henri Servaes, 1990, Additional evidence on equity ownership and corporate value, Journal of Financial Economics 27, 595-612.

Mikkelson, Wayne H., and M. Megan Partch, 1989, Managers Voting Rights and Corporate Control, Journal of Financial Economics 25, 263-290. 
Morck, Randall, Andrei Shleifer, and Robert W. Vishny, 1988, Management Ownership and Market Valuation: An Empirical Analysis, Journal of Financial Economics 20, 293-315.

Morck, Randall, Andrei Shleifer, and Robert W. Vishny, 1989, Alternative Mechanisms for Corporate Control, American Economic Review 79, 842-852.

Mukherji, Sandip, Yong H. Kim and Michael C. Walker, 1997, The effect of stock splits on the ownership structure of firms, Journal of Corporate Finance, 3, 167-188.

Schwert, G. William, 2000, Hostility in takeovers: In the eyes of the beholder?, The Journal of Finance 55, 2599-2640.

Shleifer, Andrei, and Robert W. Vishny, 1986, Large Shareholders and Corporate Control, Journal of Political Economy 94, 461-488.

Shivdasani, Anil, 1993, Board composition, ownership structure, and hostile takeovers, Journal of Accounting and Economics 16, 167-198.

Song, Moon H., and Ralph A. Walkling, 1993, The Impact of Managerial Ownership on Acquisition Attempts and Target Shareholder Wealth, Journal of Financial and Quantitative Analysis 28, 439-457.

Stulz, René M., 1988, Managerial Control of Voting Rights: Financing Policies and the Market for Corporate Control, Journal of Financial Economics 20, 25-54.

Subramanian, Guhan, 2004, The Disappearing Delaware Effect, Journal of Law, Economics, and Organization 20, 32-59. 


\section{Appendix 1: Variable Definitions}

\begin{tabular}{|c|c|}
\hline Variable & Description of Variable and Source of Data \\
\hline \multirow[t]{4}{*}{ Passiveness } & Passiveness of company non-institutional shareholder base, calculated as \\
\hline & mescineness $=-\ln d$ \\
\hline & passweness $=-\log (\overline{\text { common shareholders -institutional investors }})$ \\
\hline & $\begin{array}{l}\text { where institutional ownership is the fraction of outstanding shares owned by institutions, } \\
\text { common shareholders is the number of common shareholders of record (in thousands), } \\
\text { CCM data } 100 \text {, and institutional investors is the number of institutional investors (in } \\
\text { thousands), estimated from Spectrum 13f. }\end{array}$ \\
\hline Market Cap & Year-end equity market capitalization: (price x shares outstanding), CCM data $24 \mathrm{x}$ data 25 \\
\hline Book-to-Market, B/M & Ratio of long-term debt to the total equity of the firm: CCM data 9/ data 60 . \\
\hline Price-to-Earnings, $\mathrm{P} / \mathrm{E}$ & $\begin{array}{l}\text { Ratio of the year-end stock price to earnings per share for the prior fiscal year: CCM data } \\
\text { 24/data } 58 .\end{array}$ \\
\hline Debt-to-Equity, D/E & Ratio of long-term debt to the total equity of the firm: CCM data 9/ data 60 . \\
\hline Operating Income & Ratio of operating income to total assets: CCM data 13/ data 6 . \\
\hline Growth of Sales & $\begin{array}{l}\text { Average annual increase in company sales over the previous } 3 \text { year period, obtained from } \\
\text { CCM data item } 12 \text {. }\end{array}$ \\
\hline Cash & Ratio of cash holdings to total assets: CCM data $1 /$ data 6. \\
\hline Stock Liquidity & $\begin{array}{l}\text { Sum of the monthly share volume over the previous year divided by the number of shares } \\
\text { outstanding at the end of the year: CRSP Monthly Stocks. }\end{array}$ \\
\hline Past Year Return & Compounded monthly return for the previous year: CRSP Monthly Stocks. \\
\hline Volatility & $\begin{array}{l}\text { Stock return volatility, computed as the standard deviation of daily stock returns for the } \\
\text { previous year: CRSP Daily Stocks. }\end{array}$ \\
\hline $\begin{array}{l}\text { Capital Expendit., } \\
\text { Capex }\end{array}$ & Ratio of capital expenditure to total assets of the firm: CCM data 128/ data 6. \\
\hline ROE & $\begin{array}{l}\text { Ratio of earnings to average equity for the prior fiscal year: CCM data } 20 / \text { (data } 60+\text { data } \\
60(t-1)) / 2 \text { ). }\end{array}$ \\
\hline $\begin{array}{l}\text { Institutional } \\
\text { Ownership }\end{array}$ & $\begin{array}{l}\text { Year-end fraction of shares outstanding owned by institutional fund managers: Spectrum } \\
13 \mathrm{f} .\end{array}$ \\
\hline Industry Concentration & $\begin{array}{l}\text { Sum of the squared market share of each firm in the same industry during a year. Market } \\
\text { share is defined as the total sales of the firm in a given year divided by the total sales of the } \\
\text { industry in the year. The industry is defined at the three-digit SIC code level; the SIC codes } \\
\text { have been obtained from CRSP Monthly Stocks (SICCD). The sales data comes from } \\
\text { CCM: data } 12 \text {. }\end{array}$ \\
\hline Block ownership & Fraction of shares outstanding pertaining to shareholders with at least $5 \%$ ownership stake. \\
\hline Insider ownership & $\begin{array}{l}\text { Fraction of shares outstanding pertaining to the company management. Estimated from } \\
\text { Compact Disclosure. }\end{array}$ \\
\hline HighIO & $\begin{array}{l}\text { A dummy variable which takes the value of } 1 \text { if Institutional Ownership is above } 50 \%, 0 \\
\text { otherwise. }\end{array}$ \\
\hline HighBlock & $\begin{array}{l}\text { A dummy variable which takes the value of } 1 \text { if Block Ownership is above } 25 \%, 0 \\
\text { otherwise. }\end{array}$ \\
\hline HighInside & $\begin{array}{l}\text { A dummy variable which takes the value of } 1 \text { if Inside Ownership is above } 10 \%, 0 \\
\text { otherwise. }\end{array}$ \\
\hline $\begin{array}{l}\text { Corporate Governance } \\
\text { Index, G }\end{array}$ & $\begin{array}{l}\text { Measured as in Gompers, Ishii, and Metric (2003): sum of the number of provisions } \\
\text { restricting shareholder rights. Data obtained from IRRC. }\end{array}$ \\
\hline Poison Pill & $\begin{array}{l}\text { Poison pill dummy which takes a value of } 1 \text { if a company has a poison pill in place and } 0 \\
\text { otherwise. Data obtained from SDC. }\end{array}$ \\
\hline
\end{tabular}




\section{Appendix 2: Passiveness and insider ownership, institutional ownership, and governance}

\section{Passiveness and insider ownership}

Morck, Shleifer, and Vishny (1988) relate insider ownership to firm performance. Like block ownership, sufficiently large insider ownership will preclude a free-riding problem. In our sample the average (median) insider ownership is $17.70 \%(8.34 \%)$. This is lower than the 24\% (17\%) pre-adjusted insider ownership reported by Holderness (2009). The difference is likely because Holderness selects a random sample of approximately $10 \%$ of the firms available in Compact Disclosure. Even though insider ownership is prevalent, we find that in $53.09 \%$ (42.65\%) of firms insider ownership is below $10 \%(5 \%)$.

The correlation between insider ownership and passiveness is -0.28 ; firms with substantial managerial ownership tend to have a high average ownership per investor. As with block ownership, we sort companies into two groups by insider ownership and separately sort them in two groups by passiveness. Panel A of Table R1 presents the results; as expected given the correlation, there is a tendency for firms with large insider ownership also to have a less passive shareholder base. However, the relation is far from deterministic; $30.90 \%$ of the firms have a high insider ownership and low passiveness while $19.10 \%$ of the firms have high insider ownership and high passiveness. ${ }^{1}$

\footnotetext{
${ }^{1}$ Even though firms may have similar insider ownership, the dispersion of the remaining stake may be very different. For example, at the end of 2006, Kforce, Inc (cusip 493732) and Vital Images (cusip 92846N), two business services industry (sic2=73) companies, had very similar inside ownership (6.37\% vs. 3.48\%) and similar market capitalization ( $498 \mathrm{mln}$ vs. $588 \mathrm{mln}$ ). However, Kforce's passiveness was -0.52 , which places a company in the bottom 25\% of passiveness, whereas Vital Images's passiveness is 3.64, which corresponds to the upper $25 \%$.
} 


\section{Passiveness and institutional ownership}

Another possible concern could be that shareholder passiveness is proxying for institutional ownership. The correlation between institutional ownership and passiveness is 0.25. Firms that have a low ownership per shareholder also have high institutional ownership. The positive relation between institutional ownership and passiveness could be the result of retail investors choosing to invest in stocks that they know institutional investors have incentives to monitor.

When we sort companies in non-nested groups on institutional ownership and passiveness (Panel B of Table R1), we find that 30.90\% (15.45\%/50\%) of companies with high institutional ownership still have low passiveness. An example of such a company is Bill Barrett Corp (cusip 06846N). As of the end of 2006, its institutional ownership was about $59.21 \%$, which is similar to the $61.41 \%$ institutional ownership of Global Industries, Ltd (cusip 379336). The market capitalizations of these companies were comparable at about $1.20 \mathrm{bln}$ and $1.52 \mathrm{bln}$ respectively. Both of these companies are in the natural resource industry (sic2=13). Yet Bill Barrett is in the bottom $25 \%$ of passiveness whereas Global Industries is among top $25 \%$.

\section{Passiveness and corporate governance}

Our source of data on corporate governance is the Compustat-Investor Responsibility Research Center (IRRC) merged database for non-financial firms from 1990 to 2004. The IRRC database is available only for 1990, 1993, 1995, 1998, 2000, 2002, and 2004. Following Rauh (2006), we fill in governance characteristics for unavailable years by taking the data from the most recent year for which it is available, but not more than 5 years back 
for each firm. The Gompers et. al. (2003) governance index is used to measure the level of corporate governance. $^{2}$

We investigate whether shareholder passiveness is related to a firm's other antitakeover defenses. The correlation between passiveness and G-index is 0.22 : firms that have more anti-takeover defenses in place also tend to have a more passive shareholder base. This is also evident from the average passiveness across G-index groups (presented in Panel C of Table R1): average passiveness is steadily rising with G-index. This provides early evidence that shareholder passiveness is a substitute for other anti-takeover defenses. When we split companies into two groups by governance and into two groups by passiveness, we observe that there are $23.07 \%$ high G-index / low passiveness companies and $16.71 \%$ low G-index / high passiveness companies. If G-index fully explained passiveness these numbers should both be zero. ${ }^{3}$

\footnotetext{
${ }^{2}$ Occasionally, we consider whether a firm has a poison pill in place as a specific anti-takeover provision. In this case, we define an indicator variable that takes the value of 1 if a poison pill is present.

${ }^{3}$ The examples of Aptar Group (cusip 038336) [consumer products, cosmetics] and Amsurg (cusip 03232P) [healthcare] illustrate that passiveness is a distinct characteristic from the G-index. Both of these firms have a well above median ( $=9$ out 18 ) G-index of 11 , suggesting management of these companies is entrenched; they are also among the top 25\% of companies in terms of market cap. Aptar's passiveness is -1.07 and Amsurg's passiveness is 5.82, which puts them in the bottom and top quartile of passiveness respectively.
} 


\section{Table 1: descriptive statistics}

We present descriptive statistics on the variables used in our study. Derived Equity Stake, \% (\$) is the ratio of fraction of shares outstanding (its dollar value) owned by non-institutional shareholders divided by the number of non-institutional shareholders. Ownership per Institutional Investor is the percentage of company shares outstanding (its dollar value) owned by an institutional investor. Passiveness is the fraction of shares outstanding owned by the average non-institutional shareholder. All other variables are described in Appendix 1. All variables are winsorized at $1 \%$ and $99 \%$ of the distribution. The full sample covers the period between 1981 and 2007 and contains 83,611 observations. The sample with available block and institutional ownership data covers the 1991 to 2006 time period and contains 39,557 observations.

\section{Full sample}

\begin{tabular}{lccccc} 
& Mean & Median & StDev & Q1 & Q3 \\
\hline Derived Equity Stake, \% & 0.0250 & 0.0172 & 0.0237 & 0.0054 & 0.0390 \\
Derived Equity Stake, \$ (ths) & 138.1422 & 31.3590 & 716.9575 & 10.8151 & 93.7530 \\
Ownership per Inst Investor, \% & 0.8981 & 0.5763 & 1.4058 & 0.2619 & 1.1263 \\
Ownership per Inst Investor, \$ (mln) & 4.7044 & 1.9101 & 10.7203 & 0.4889 & 5.0986 \\
Passiveness & 0.9568 & 0.7661 & 1.9279 & -0.3540 & 2.1319 \\
Institutional Ownership (IO) & 0.3058 & 0.2412 & 0.2667 & 0.0653 & 0.5026 \\
Log(market cap) & 4.8121 & 4.7236 & 2.2552 & 3.2220 & 6.3293 \\
Log (B/M) & -0.8422 & -0.6513 & 1.1113 & -1.3106 & -0.1334 \\
ROA & 0.0512 & 0.0372 & 0.4829 & -0.0359 & 0.0690 \\
CAPEX & 0.0604 & 0.0389 & 0.0715 & 0.0144 & 0.0781 \\
Cash & 0.1472 & 0.0850 & 0.6434 & 0.0220 & 0.3059 \\
D/E & 0.5704 & 0.2069 & 1.7008 & 0.0011 & 0.7171 \\
P/E & 10.3518 & 10.8173 & 47.6996 & -2.0818 & 19.7917 \\
Growth of Sales & 0.0812 & 0.0837 & 0.4498 & -0.0358 & 0.2246 \\
Past Year Return & 0.0506 & 0.0911 & 0.6496 & -0.2425 & 0.3789 \\
Volatility & 0.0089 & 0.0040 & 0.0142 & 0.0015 & 0.0098 \\
Industry Concentration & 0.0774 & 0.0482 & 0.0761 & 0.0325 & 0.0925 \\
Stock Liquidity & 1.0676 & 0.6260 & 1.3518 & 0.2652 & 1.3135 \\
& & & & & \\
Sample with available block and insider ownership & & & \\
Passiveness & 0.9028 & 0.7072 & 2.0271 & -0.5053 & 2.1679 \\
Institutional Ownership & 0.3450 & 0.3004 & 0.2766 & 0.0891 & 0.5672 \\
Block Ownership & 0.3666 & 0.3318 & 0.2851 & 0.1242 & 0.5621 \\
Insider Ownership & 0.1770 & 0.0834 & 0.2223 & 0.0104 & 0.2683 \\
\hline
\end{tabular}




\section{Table 2: Validation of US-based measure of passiveness with Swedish data}

We compare the dollar values of derived equity stakes for the US and Sweden and calculate measures of passiveness for Swedish firms using actual positions and derived equity stakes of Swedish non-institutional investors. Actual position value of non-institutional investors (non-institutional investors with direct ownership) is calculated as the number of shares $\mathrm{x}$ share price (expressed in US dollars); we consider equity positions held by non-institutional shareholders both directly and through a brokerage (directly only). We define dollar values of derived equity stakes as follows

$\$$ Value of Derived Equity Stake $(U S)=\frac{\text { Market Capitalization } \times(1-I O)}{\text { common shareholders }- \text { institutional investors }}$

\$Value of Derived Equity Stake (Sweden, direct ownership) $=$

$$
=\frac{\text { Market Capitalization } \times(1-I O)}{\text { non }- \text { institutional investors with direct ownership }}
$$

Measures of Passiveness for Swedish data are defined as

Actual Passiveness $=-\log ($ average fraction of shares oustanding per non - institutional investor $)$

$$
\text { Passiveness }=-\log \left(\frac{1-I O}{\text { non }- \text { institutional investors with direct ownership }(\text { in thousands })}\right)
$$

\begin{tabular}{lcc} 
US & Mean & Median \\
\hline \$ value of Derived Equity Stake, \$ (ths) & 138.142 & 31.359 \\
Sweden & & \\
\hline \% positions held by non-institutional investors in direct ownership & & \\
Actual Position value of non-institutional investors, \$(ths) & 24.245 & 0.378 \\
Actual Position value of non-institutional investors (direct ownership), \$(ths) & 28.650 & 0.444 \\
\$ Value of Derived Equity Stake (direct ownership), ths(\$) & 181.316 & 33.879 \\
Actual Passiveness (actual position of non-institutional investors) & 1.719 & 1.516 \\
Passiveness (Derived Equity stake of (direct ownership)) & 0.398 & 0.194 \\
Correlation(Actual Passiveness, Passiveness) & & \\
$\mathrm{R}^{2}$ of regression of Actual Passiveness on Passiveness & & 0.955 \\
\hline
\end{tabular}




\section{Table 3: Passiveness and likelihood of receiving a bid}

We report the relation between shareholder passiveness and the likelihood of receiving an M\&A bid. The dependent variable takes the value of 1 if the company receives an M\&A bid over the following year and 0 otherwise. Passiveness is the fraction of shares outstanding owned by the average non-institutional shareholder. HighIO (HighBlock, HighInside) is a dummy variable which takes the value of 1 if Institutional Ownership is above 50\% (Block Ownership is above $25 \%$, Insider Ownership is above 10\%) and 0 otherwise. F-tests for the difference between interactive coefficients are presented as well. All variables are described in Appendix 1.

\begin{tabular}{|c|c|c|c|c|c|c|c|c|c|c|c|c|c|c|c|}
\hline & \multicolumn{3}{|c|}{ (1) } & \multicolumn{3}{|c|}{ (2) } & \multicolumn{3}{|c|}{ (3) } & \multicolumn{3}{|c|}{ (4) } & \multicolumn{3}{|c|}{ (5) } \\
\hline & estimate & t-stat & ME & estimate & t-stat & $\mathrm{ME}$ & estimate & t-stat & ME & estimate & t-stat & ME & estimate & t-stat & $\mathrm{ME}$ \\
\hline Passiveness & -0.031 & $(-3.95)$ & -0.002 & -0.029 & $(-3.05)$ & -0.002 & & & & & & & & & \\
\hline$\times$ HighIO & & & & & & & -0.021 & $(-1.52)$ & -0.001 & & & & & & \\
\hline × (1-HighIO $)$ & & & & & & & -0.037 & $(-4.22)$ & -0.002 & & & & & & \\
\hline$\times$ HighBlock & & & & & & & & & & -0.024 & $(-2.08)$ & -0.001 & & & \\
\hline × (1-HighBlock) & & & & & & & & & & -0.036 & $(-3.75)$ & -0.002 & & & \\
\hline$\times$ HighIO or Highl & Block or $\mathrm{H}$ & IighInside & & & & & & & & & & & -0.022 & $(-2.00)$ & -0.001 \\
\hline$\times(1-$ HighIO or $\mathrm{H}$ & ighBlock c & or HighIn & side) & & & & & & & & & & -0.067 & $(-6.30)$ & -0.004 \\
\hline Inst. Ownership & 0.355 & $(6.30)$ & 0.025 & 0.024 & $(0.34)$ & 0.001 & 0.074 & $(1.20)$ & 0.004 & 0.076 & $(1.22)$ & 0.004 & 0.075 & $(1.23)$ & 0.004 \\
\hline Insider Ownership & & & & 0.076 & $(1.22)$ & 0.004 & 0.025 & $(0.36)$ & 0.001 & 0.016 & $(0.21)$ & 0.001 & 0.022 & $(0.32)$ & 0.001 \\
\hline Block Ownership & & & & 0.391 & $(6.15)$ & 0.022 & 0.365 & $(5.43)$ & 0.021 & 0.381 & $(5.87)$ & 0.022 & 0.348 & $(5.21)$ & 0.020 \\
\hline $\log ($ size $)$ & -0.007 & $(-0.87)$ & 0.000 & -0.008 & $(-0.96)$ & 0.000 & -0.009 & $(-1.03)$ & 0.000 & -0.007 & $(-0.78)$ & 0.000 & -0.006 & $(-0.72)$ & 0.000 \\
\hline $\log (\mathrm{B} / \mathrm{M})$ & 0.032 & $(3.35)$ & 0.002 & 0.015 & $(1.05)$ & 0.001 & 0.015 & $(1.08)$ & 0.001 & 0.015 & $(1.08)$ & 0.001 & 0.016 & $(1.16)$ & 0.001 \\
\hline ROA & 0.001 & $(1.55)$ & 0.000 & 0.011 & $(1.78)$ & 0.001 & 0.011 & (1.79) & 0.001 & 0.011 & $(1.78)$ & 0.001 & 0.011 & (1.78) & 0.001 \\
\hline Capex & -0.040 & $(-0.34)$ & -0.003 & 0.351 & $(1.73)$ & 0.020 & 0.356 & $(1.76)$ & 0.020 & 0.346 & $(1.70)$ & 0.020 & 0.346 & $(1.70)$ & 0.020 \\
\hline Cash & -0.006 & $(-0.50)$ & 0.000 & 0.004 & $(0.32)$ & 0.000 & 0.004 & $(0.32)$ & 0.000 & 0.004 & $(0.30)$ & 0.000 & 0.003 & $(0.27)$ & 0.000 \\
\hline $\mathrm{D} / \mathrm{E}$ & 0.003 & $(0.60)$ & 0.000 & -0.009 & $(-1.00)$ & -0.001 & -0.009 & $(-1.00)$ & -0.001 & -0.009 & $(-1.00)$ & -0.001 & -0.009 & $(-1.02)$ & -0.001 \\
\hline $\mathrm{P} / \mathrm{E}$ & 0.000 & $(-2.05)$ & 0.000 & 0.000 & $(-0.86)$ & 0.000 & 0.000 & $(-0.84)$ & 0.000 & 0.000 & $(-0.86)$ & 0.000 & 0.000 & $(-0.82)$ & 0.000 \\
\hline Growth of Sales & 0.033 & $(1.04)$ & 0.002 & 0.029 & $(0.68)$ & 0.002 & 0.029 & $(0.68)$ & 0.002 & 0.028 & $(0.66)$ & 0.002 & 0.027 & $(0.65)$ & 0.002 \\
\hline Past Year Return & -0.019 & $(-1.30)$ & -0.001 & -0.010 & $(-0.62)$ & -0.001 & -0.009 & $(-0.54)$ & -0.001 & -0.011 & $(-0.66)$ & -0.001 & -0.011 & $(-0.66)$ & -0.001 \\
\hline Volatility & 0.405 & $(0.49)$ & 0.028 & 1.149 & $(1.06)$ & 0.065 & 1.053 & $(0.94)$ & 0.060 & 1.189 & $(1.10)$ & 0.067 & 1.118 & $(1.01)$ & 0.063 \\
\hline Industry Concentr. & -0.394 & $(-1.04)$ & -0.028 & -0.214 & $(-0.44)$ & -0.012 & -0.235 & $(-0.48)$ & -0.013 & -0.214 & $(-0.44)$ & -0.012 & -0.225 & $(-0.47)$ & -0.013 \\
\hline Stock Liquidity & 0.049 & $(6.59)$ & 0.003 & 0.030 & $(4.05)$ & 0.002 & 0.031 & $(4.09)$ & 0.002 & 0.029 & $(4.04)$ & 0.002 & 0.030 & $(4.09)$ & 0.002 \\
\hline Industry FE & & Sic2 & & & Sic2 & & & Sic2 & & & Sic2 & & & $\operatorname{Sic} 2$ & \\
\hline Time FE & & Yes & & & Yes & & & Yes & & & Yes & & & Yes & \\
\hline Clustering & & Sic2 & & & Sic2 & & & $\operatorname{Sic} 2$ & & & $\operatorname{Sic} 2$ & & & Sic2 & \\
\hline F-test & & & & & & & 6.15 & $(0.02)$ & & 4.07 & $(0.05)$ & & 7.87 & $(0.01)$ & \\
\hline Adjusted $\mathrm{R}^{2}$ & & 0.0669 & & & 0.0797 & & & 0.0799 & & & 0.0798 & & & 0.0804 & \\
\hline $\mathrm{N}$ & & 83,611 & & & 39,557 & & & 39,557 & & & 39,557 & & & 39,557 & \\
\hline
\end{tabular}


Table 4: Passiveness and likelihood of deal completion

We report the relation between shareholder passiveness and the likelihood of M\&A deal completion. The dependent variables take the value of 1 if the takeover bid has been successful and 0 otherwise. Passiveness is the fraction of shares outstanding owned by the average non-institutional shareholder. HighIO (HighBlock, HighInside) is a dummy variable which takes the value of 1 if Institutional Ownership is above 50\% (Block Ownership is above 25\%, Insider Ownership is above 10\%) and 0 otherwise. Poison Pill takes the value of 1 if a firm has a poison pill in place and 0 otherwise. All variables are described in Appendix 1.

(1)

estimate t-stat ME estimate t-stat ME

\begin{tabular}{lccccccccc} 
& estimate & $\mathrm{t}-\mathrm{stat}$ & $\mathrm{ME}$ & estimate & $\mathrm{t}-\mathrm{stat}$ & $\mathrm{ME}$ & estimate & $\mathrm{t}-\mathrm{stat}$ & $\mathrm{ME}$ \\
\hline Passiveness & -0.082 & $(-4.38)$ & -0.030 & -0.063 & $(-3.25)$ & -0.022 & & & \\
$\times$ HighIO & & & & & & & -0.060 & $(-2.03)$ & -0.021 \\
$\times(1-$ HighIO $)$ & & & & & & & -0.065 & $(-2.68)$ & -0.023
\end{tabular}

$\times$ HighBlock

$\times(1$-HighBlock $)$

$\times$ HighIO or HighBlock or HighInside

$\times(1-$ HighIO or HighBlock or HighInside)

$\times$ poison pill

$\times$ no poison pill

Inst. Ownership

Insider Ownership

Block Ownership

$\log ($ size $)$

$\log (\mathrm{B} / \mathrm{M})$

ROA

Capex

Cash

$\mathrm{D} / \mathrm{E}$

$\mathrm{P} / \mathrm{E}$

Growth of Sales

Past Year Return

Volatility

Industry Concentr

Stock Liquidity

CashDeal

Hostile

Merger

Poison Pill

Industry FE

Time FE

Clustering

Adjusted $\mathrm{R}^{2}$

$\mathrm{N}$

$0.288 \quad(2.95) \quad 0.106$

0.223

0.196

0.321

$\begin{array}{lllll}0.023 & (1.21) & 0.008 & 0.011\end{array}$

$\begin{array}{lll}-0.022 & (-0.90) & -0.008\end{array}$

$\begin{array}{lll}0.136 & (3.24) & 0.050\end{array}$

$\begin{array}{llll}-0.080 & (-0.24) & -0.030 & -0.229\end{array}$

$-0.021$

$\begin{array}{lll}0.027 & (1.07) & 0.010\end{array}$

$\begin{array}{lll}-0.003 & (-0.25) & -0.001\end{array}$

$\begin{array}{llll}0.001 & (1.25) & 0.000\end{array}$

$-0.070 \quad(-1.87)-0.026$

$\begin{array}{llll}-0.020 & (-0.48) & -0.007\end{array}$

$\begin{array}{ccc}-0.673 & (-0.32) & -0.247 \\ 0.380 & (0.80) & 0.139\end{array}$

$\begin{array}{lll}0.380 & (0.80) & 0.139\end{array}$

$\begin{array}{lll}-0.026 & (-1.29) & -0.010 \\ 0.160 & (2.76) & 0.058\end{array}$

$\begin{array}{ccc}0.160 & (2.76) & 0.058 \\ -0.683 & (-4.52) & -0.267\end{array}$

$\begin{array}{lll}0.115 & (0.48) & 0.041\end{array}$

$\begin{array}{lll}-0.325 & (-1.84) & -0.125\end{array}$

Sic2

Yes

Sic2

0.0812

4,636

$\begin{array}{ccc}-0.229 & (-0.48) & -0.081\end{array}$

$\begin{array}{llll}0.025 & (0.97) & 0.009\end{array}$

$\begin{array}{lll}-0.010 & (-0.74) & -0.004\end{array}$

(1.18) 0.000

$\begin{array}{lll}-0.066 & (-1.36) & -0.023\end{array}$

$(-0.79)-0.009$

$-2.763 \quad(-1.23)-0.975$

$\begin{array}{lll}-0.637 & (-0.69) & -0.225\end{array}$

$\begin{array}{llll}-0.003 & (-0.14) & -0.001\end{array}$

(1.53) 0.033

$-1.065$

$(-5.49) \quad-0.406$

0.107

$\begin{array}{ll}0.43) \quad 0.037 \\ -(-0.52) & -0.055\end{array}$

$\mathrm{Sic} 2$

Yes

Sic2

0.1004

2,929 $\begin{array}{lll}-0.061 & (-2.62) & -0.022\end{array}$ $\begin{array}{lll}-0.065 & (-2.98) & -0.023\end{array}$

$\begin{array}{lll}-0.042 & (-1.02) & -0.015\end{array}$ $\begin{array}{llll}-0.068 & (-3.40) & -0.024\end{array}$

$-0.090 \quad(-0.70) \quad-0.032$

$\begin{array}{llll}-0.063 & (-3.27) & -0.022\end{array}$

$\begin{array}{lll}0.320 & (2.66) & 0.113\end{array}$

$\begin{array}{llll}0.223 & (1.42) & 0.079\end{array}$

$\begin{array}{llllllllllll}(2.25) & 0.111 & 0.318 & (2.56) & 0.112 & 0.340 & (2.67) & 0.120 & 0.197 & (1.84) & 0.069 \\ (0.48) & 0.004 & 0.012 & (0.51) & 0.004 & 0.011 & (0.45) & 0.004 & 0.011 & (0.48) & 0.004\end{array}$

$\begin{array}{cccccccccccc}(0.48) & 0.004 & 0.012 & (0.51) & 0.004 & 0.011 & (0.45) & 0.004 & 0.011 & (0.48) & 0.004 \\ (-0.75) & -0.008 & -0.021 & (-0.75) & -0.008 & -0.022 & (-0.76) & -0.008 & -0.021 & (-0.75) & -0.008\end{array}$

$\begin{array}{llllllllllll}(3.61) & 0.054 & 0.153 & (3.61) & 0.054 & 0.154 & (3.64) & 0.054 & 0.153 & (3.63) & 0.054\end{array}$

$\begin{array}{llllllllllll}-0.227 & (-0.48) & -0.080 & -0.229 & (-0.48) & -0.081 & -0.229 & (-0.48) & -0.081 & -0.227 & (-0.48) & -0.080\end{array}$

$\begin{array}{lllllllllllll}0.025 & (0.96) & 0.009 & 0.025 & (0.95) & 0.009 & 0.027 & (1.03) & 0.009 & 0.025 & (0.97) & 0.009\end{array}$

$\begin{array}{lllllllllllll}-0.010 & (-0.74) & -0.004 & -0.010 & (-0.74) & -0.004 & -0.010 & (-0.73) & -0.004 & -0.010 & (-0.74) & -0.004\end{array}$

$\begin{array}{lllllllllllll}0.001 & (1.18) & 0.000 & 0.001 & (1.18) & 0.000 & 0.001 & (1.16) & 0.000 & 0.001 & (1.18) & 0.000\end{array}$

$\begin{array}{lllllllllllll}-0.066 & (-1.36) & -0.023 & -0.067 & (-1.37) & -0.024 & -0.066 & (-1.34) & -0.023 & -0.066 & (-1.36) & -0.023\end{array}$

$\begin{array}{llllllllllll}-0.025 & (-0.78) & -0.009 & -0.025 & (-0.80) & -0.009 & -0.025 & (-0.77) & -0.009 & -0.025 & (-0.79) & -0.009\end{array}$

$\begin{array}{llllllllllllll}-2.796 & (-1.24) & -0.987 & -2.726 & (-1.25) & -0.962 & -2.793 & (-1.25) & -0.985 & -2.753 & (-1.23) & -0.971\end{array}$

$\begin{array}{lllllllllllll}-0.647 & (-0.70) & -0.228 & -0.640 & (-0.69) & -0.226 & -0.616 & (-0.66) & -0.217 & -0.629 & (-0.68) & -0.222\end{array}$

$\begin{array}{llllllllllllll}-0.002 & (-0.12) & -0.001 & -0.003 & (-0.16) & -0.001 & -0.003 & (-0.18) & -0.001 & -0.003 & (-0.15) & -0.001\end{array}$

$\begin{array}{llllllllllll}0.094 & (1.54) & 0.033 & 0.094 & (1.53) & 0.033 & 0.093 & (1.53) & 0.032 & 0.094 & \text { (1.54) } & 0.033\end{array}$

$\begin{array}{llllllllllllll}-1.066 & (-5.55) & -0.406 & -1.065 & (-5.49) & -0.405 & -1.062 & (-5.56) & -0.405 & -1.059 & (-5.30) & -0.403\end{array}$

$\begin{array}{lllllllllllll}0.106 & (0.42) & 0.037 & 0.107 & (0.43) & 0.037 & 0.106 & (0.43) & 0.036 & 0.105 & (0.42) & 0.036\end{array}$

$\begin{array}{llllllllll}-0.153 & (-0.52) & -0.056 & -0.147 & (-0.50) & -0.053 & -0.101 & (-0.28) & -0.036\end{array}$

$\mathrm{Sic} 2$

Yes

Sic2

0.1004

2,929
Sic2

Yes

Sic2

0.1004

2,929 


\section{Table 5: Passiveness and premium}

We report the relation between shareholder passiveness and M\&A premium. The dependent variable is abnormal return on the target company stock over the (-62:+42) days event window around the M\&A bid announcement. Passiveness is the fraction of shares outstanding owned by the average non-institutional shareholder. HighIO (HighBlock, HighInside) is a dummy variable which takes the value of 1 if Institutional Ownership is above 50\% (Block Ownership is above 25\%, Insider Ownership is above 10\%) and 0 otherwise. Poison Pill takes the value of 1 if a firm has a poison pill in place and 0 otherwise. F-tests for the difference between interactive coefficients are presented as well. All variables are described in Appendix 1.

(1)

(2)

(3)

(4)

(5)

(6)

\begin{tabular}{|c|c|c|c|c|c|c|c|c|c|c|c|c|}
\hline & estimate & t-stat & estimate & t-stat & estimate & t-stat & estimate & t-stat & estimate & t-stat & estimate & t-stat \\
\hline Passiveness & 0.012 & $(2.23)$ & 0.023 & $(3.77)$ & & & & & & & & \\
\hline$\times$ HighIO & & & & & 0.002 & $(0.42)$ & & & & & & \\
\hline$\times(1$-HighIO $)$ & & & & & 0.037 & $(4.32)$ & & & & & & \\
\hline$\times$ HighBlock & & & & & & & 0.008 & $(1.12)$ & & & & \\
\hline × (1-HighBlock) & & & & & & & 0.041 & $(4.31)$ & & & & \\
\hline$\times$ HighIO or Highl & Block or $\mathrm{H}$ & ighInside & & & & & & & 0.011 & $(1.83)$ & & \\
\hline$\times(1-$ HighIO or $\mathrm{H}$ & ighBlock o & r HighIns & side) & & & & & & 0.072 & $(5.35)$ & & \\
\hline$\times$ poison pill & & & & & & & & & & & 0.024 & $(0.55)$ \\
\hline$\times$ no poison pill & & & & & & & & & & & 0.023 & (3.69) \\
\hline Inst. Ownership & 0.272 & $(4.86)$ & 0.237 & $(4.04)$ & 0.289 & $(4.59)$ & 0.254 & $(4.19)$ & 0.159 & $(2.83)$ & 0.157 & $(2.58)$ \\
\hline Insider Ownership & & & 0.157 & $(2.58)$ & 0.164 & $(2.73)$ & 0.157 & $(2.64)$ & 0.247 & $(5.35)$ & 0.240 & $(5.11)$ \\
\hline Block Ownership & & & 0.240 & $(5.09)$ & 0.235 & $(4.92)$ & 0.263 & $(5.66)$ & 0.279 & $(4.48)$ & 0.237 & $(4.05)$ \\
\hline $\log ($ size $)$ & -0.031 & $(-3.14)$ & -0.027 & $(-2.51)$ & -0.024 & $(-2.33)$ & -0.032 & $(-2.90)$ & -0.028 & $(-2.69)$ & -0.027 & $(-2.52)$ \\
\hline $\log (\mathrm{B} / \mathrm{M})$ & 0.103 & $(6.32)$ & 0.112 & $(5.47)$ & 0.113 & $(5.70)$ & 0.111 & $(5.43)$ & 0.111 & $(5.59)$ & 0.112 & $(5.47)$ \\
\hline ROA & 0.092 & $(1.71)$ & 0.070 & $(1.09)$ & 0.067 & $(1.05)$ & 0.072 & $(1.11)$ & 0.072 & $(1.12)$ & 0.070 & (1.09) \\
\hline Capex & 0.224 & $(1.41)$ & 0.119 & $(0.80)$ & 0.106 & $(0.71)$ & 0.122 & $(0.81)$ & 0.118 & $(0.76)$ & 0.119 & $(0.80)$ \\
\hline Cash & -0.042 & $(-2.96)$ & -0.033 & $(-3.13)$ & -0.032 & $(-3.32)$ & -0.031 & $(-3.15)$ & -0.029 & $(-3.19)$ & -0.033 & $(-3.13)$ \\
\hline $\mathrm{D} / \mathrm{E}$ & -0.005 & $(-1.01)$ & -0.006 & $(-0.88)$ & -0.006 & $(-0.92)$ & -0.005 & $(-0.83)$ & -0.005 & $(-0.83)$ & -0.006 & $(-0.88)$ \\
\hline $\mathrm{P} / \mathrm{E}$ & 0.000 & $(2.21)$ & 0.001 & $(3.02)$ & 0.000 & $(2.93)$ & 0.001 & $(3.10)$ & 0.000 & $(3.06)$ & 0.001 & $(3.06)$ \\
\hline Growth of Sales & -0.047 & $(-1.75)$ & -0.062 & $(-1.94)$ & -0.063 & $(-1.94)$ & -0.058 & $(-1.85)$ & -0.061 & $(-1.92)$ & -0.062 & $(-1.94)$ \\
\hline Past Year Return & 0.098 & $(5.23)$ & 0.082 & $(3.97)$ & 0.079 & $(3.91)$ & 0.084 & $(4.07)$ & 0.083 & $(4.08)$ & 0.082 & (3.98) \\
\hline Volatility & 4.341 & $(4.32)$ & 2.256 & $(1.85)$ & 2.505 & $(2.04)$ & 1.966 & $(1.63)$ & 2.178 & $(1.77)$ & 2.255 & $(1.85)$ \\
\hline Industry Concentr & 0.015 & $(0.05)$ & -0.262 & $(-0.97)$ & -0.190 & $(-0.67)$ & -0.236 & $(-0.86)$ & -0.208 & $(-0.73)$ & -0.263 & $(-0.97)$ \\
\hline Stock Liquidity & -0.016 & $(-2.79)$ & -0.004 & $(-0.76)$ & -0.006 & $(-1.27)$ & -0.002 & $(-0.37)$ & -0.005 & $(-1.05)$ & -0.004 & $(-0.76)$ \\
\hline CashDeal & 0.097 & $(5.34)$ & 0.062 & $(2.49)$ & 0.060 & $(2.43)$ & 0.059 & $(2.43)$ & 0.059 & $(2.45)$ & 0.062 & $(2.50)$ \\
\hline Hostile & 0.065 & $(1.54)$ & 0.071 & $(1.45)$ & 0.079 & $(1.81)$ & 0.068 & $(1.36)$ & 0.078 & $(1.92)$ & 0.071 & $(1.38)$ \\
\hline Merger & -0.222 & $(-4.08)$ & -0.242 & $(-4.87)$ & -0.240 & $(-4.86)$ & -0.248 & $(-4.66)$ & -0.249 & $(-4.96)$ & -0.242 & $(-4.91)$ \\
\hline Poison Pill & 0.057 & $(1.63)$ & 0.046 & $(0.61)$ & 0.046 & $(0.65)$ & 0.050 & $(0.66)$ & 0.058 & $(0.83)$ & 0.044 & $(0.34)$ \\
\hline industry FE & Sic2 & & Sic2 & & Sic2 & & Sic2 & & Sic2 & & Sic2 & \\
\hline Time FE & Yes & & Yes & & Yes & & Yes & & Yes & & Yes & \\
\hline Clustering & Sic2 & & Sic2 & & Sic2 & & Sic2 & & Sic2 & & Sic2 & \\
\hline F-test & & & & & 11.51 & $(0.01)$ & 9.17 & $(0.01)$ & 15.22 & $(0.01)$ & 0.03 & $(0.98)$ \\
\hline Adjusted $\mathrm{R}^{2}$ & 0.1451 & & 0.18 & & 0.1831 & & 0.183 & & 0.1864 & & 0.18 & \\
\hline $\mathrm{N}$ & 4,642 & & 2,952 & & 2,952 & & 2,952 & & 2,952 & & 2,952 & \\
\hline
\end{tabular}




\section{Table 6: Managing passiveness}

We relate change in passiveness between year $t$ and $t+1$ to corporate events undertaken in year $t$. Split (Reverse Split, Rep, and SEO) is a dummy which equals 1 if a company undertook a stock split (reverse split, repurchase, or SEO) in year $t$ and 0 otherwise. Stock split (size) is the number of new shares that have been created for every old share; zero if no stock split done. Reverse split (size) is the number of old shares which were aggregated into one new share minus one; zero if no reverse split done. SEO (size) is the percentage increase in the number of shares outstanding following the SEO divided by 100; zero if no SEO done. Repurchase (size) is the percentage decrease in the number of shares outstanding following a repurchase divided by 100 , zero if no repurchase done. $\Delta$ Institutional Ownership ( $\Delta$ Insider Ownership, $\Delta$ Block Ownership) is a change in institutional (block, insider) ownership between year $t$ and $t+1$. All other variables are measured as of the end of year t. All other variables are described in Appendix 1.

(2)

(3)

(4)

\begin{tabular}{|c|c|c|c|c|c|c|c|c|}
\hline & estimate & t-stat & estimate & t-stat & estimate & t-stat & estimate & t-stat \\
\hline Split (dummy) & 0.021 & $(1.87)$ & & & 0.060 & $(4.75)$ & & \\
\hline Split (size) & & & 0.019 & $(1.95)$ & & & 0.051 & $(3.42)$ \\
\hline Reverse Split (dummy) & -0.059 & $(-1.50)$ & & & -0.125 & $(-3.67)$ & & \\
\hline Reverse Split (size) & & & -0.004 & $(-1.42)$ & & & -0.010 & $(-3.21)$ \\
\hline Repurchase (dummy) & -0.037 & $(-3.92)$ & & & -0.045 & $(-5.85)$ & & \\
\hline Repurchase (size) & & & -0.246 & $(-3.94)$ & & & -0.179 & $(-3.29)$ \\
\hline SEO (dummy) & 0.068 & $(3.65)$ & & & 0.069 & $(4.30)$ & & \\
\hline SEO (size) & & & 0.165 & $(1.99)$ & & & 0.184 & $(2.64)$ \\
\hline Inst. Ownership & -0.135 & $(-7.39)$ & -0.138 & $(-7.77)$ & 0.104 & $(5.86)$ & 0.100 & $(5.70)$ \\
\hline Insider Ownership & 0.039 & $(2.72)$ & 0.040 & $(2.80)$ & 0.071 & $(4.40)$ & 0.074 & $(4.58)$ \\
\hline Block Ownership & -0.005 & $(-0.36)$ & -0.005 & $(-0.34)$ & -0.005 & $(-0.58)$ & -0.007 & $(-0.74)$ \\
\hline$\Delta$ Inst. Ownership & & & & & 2.188 & $(29.25)$ & 2.184 & $(29.00)$ \\
\hline$\Delta$ Insider Ownership & & & & & 0.081 & $(3.25)$ & 0.081 & $(3.22)$ \\
\hline$\Delta$ Block Ownership & & & & & 0.040 & $(2.40)$ & 0.037 & $(2.22)$ \\
\hline $\log ($ size $)$ & 0.020 & $(8.18)$ & 0.020 & $(8.51)$ & -0.001 & $(-0.37)$ & -0.001 & $(-1.08)$ \\
\hline $\log (\mathrm{B} / \mathrm{M})$ & -0.007 & $(-2.56)$ & -0.007 & $(-2.68)$ & -0.010 & $(-4.11)$ & -0.011 & $(-4.28)$ \\
\hline ROA & 0.001 & $(0.63)$ & 0.000 & $(0.57)$ & -0.001 & $(-1.03)$ & -0.001 & $(-1.07)$ \\
\hline Capex & 0.156 & $(2.78)$ & 0.164 & $(2.84)$ & 0.090 & $(1.45)$ & 0.101 & $(1.58)$ \\
\hline Cash & 0.002 & $(2.96)$ & 0.003 & $(3.42)$ & 0.003 & (2.89) & 0.003 & $(3.64)$ \\
\hline $\mathrm{D} / \mathrm{E}$ & 0.000 & $(0.27)$ & 0.001 & $(0.32)$ & 0.000 & $(0.16)$ & 0.000 & $(0.19)$ \\
\hline $\mathrm{P} / \mathrm{E}$ & 0.000 & $(0.03)$ & 0.000 & $(-0.04)$ & 0.000 & $(-0.12)$ & 0.000 & $(-0.16)$ \\
\hline Growth of Sales & 0.017 & $(1.70)$ & 0.018 & $(1.77)$ & 0.020 & $(1.83)$ & 0.022 & (1.94) \\
\hline Past Year Return & 0.034 & $(6.52)$ & 0.034 & $(6.53)$ & -0.004 & $(-0.69)$ & -0.003 & $(-0.62)$ \\
\hline Volatility & -1.026 & $(-4.67)$ & -1.012 & $(-4.91)$ & 0.475 & $(2.62)$ & 0.472 & $(2.70)$ \\
\hline Industry Concentr. & 0.044 & $(0.20)$ & 0.045 & $(0.21)$ & 0.152 & $(0.93)$ & 0.154 & $(0.94)$ \\
\hline Stock Liquidity & 0.007 & $(2.57)$ & 0.0081 & $(2.76)$ & 0.0078 & $(3.60)$ & 0.009 & $(3.70)$ \\
\hline Industry FE & Sic2 & & Sic2 & & Sic2 & & Sic2 & \\
\hline Time FE & Yes & & Yes & & Yes & & Yes & \\
\hline Clustering & Sic2 & & Sic2 & & Sic2 & & Sic2 & \\
\hline Adjusted $\mathrm{R}^{2}$ & 0.023 & & 0.0255 & & 0.225 & & 0.2266 & \\
\hline $\mathrm{N}$ & 34,029 & & 34,028 & & 30,742 & & 30,741 & \\
\hline
\end{tabular}




\section{Table 7: The effect of anti-takeover law adoption in Delaware and shareholder passiveness}

We report the results of the effect of the introduction of anti-takeover legislation in Delaware on shareholder passiveness. The dependent variable is shareholder passiveness defined as the fraction of shares outstanding owned by the average non-institutional shareholder. Post1995 is a dummy variable taking the value of 1 if the year is 1996 or later and 0 otherwise. Delaware is a dummy variable which takes the value of 1 if a firm is incorporated in the state of Delaware and 0 otherwise. All variables are described in Appendix 1.

(1)

\begin{tabular}{|c|c|c|c|c|c|c|c|c|}
\hline & estimate & t-stat & estimate & t-stat & estimate & t-stat & estimate & t-stat \\
\hline post1995 & -0.351 & $(-10.78)$ & -0.373 & $(-12.79)$ & -0.299 & $(-7.84)$ & -0.392 & $(-4.26)$ \\
\hline Delaware & 0.176 & $(1.38)$ & 0.049 & $(0.46)$ & -0.022 & $(-0.20)$ & -0.222 & $(-1.72)$ \\
\hline Post1995 $\times$ Delaware & -0.221 & $(-2.87)$ & -0.105 & $(-1.79)$ & -0.213 & $(-2.79)$ & -0.299 & $(-2.47)$ \\
\hline Poison Pill (pre 1995) & & & & & 0.199 & $(6.99)$ & & \\
\hline Gindex & & & & & & & 0.016 & $(2.42)$ \\
\hline Post1995 $\times$ Poison Pill & & & & & -0.109 & $(-2.56)$ & & \\
\hline Post $1995 \times$ Gindex & & & & & & & 0.003 & $(0.28)$ \\
\hline Delaware $\times$ Poison Pill & & & & & 0.102 & $(2.51)$ & & \\
\hline Delaware $\times$ Gindex & & & & & & & 0.026 & (3.61) \\
\hline Post1995 × Delaware * & Poison Pill & & & & 0.199 & (3.29) & & \\
\hline Post1995 $\times$ Delaware $*$ & Gindex & & & & & & 0.021 & $(2.09)$ \\
\hline Inst. Ownership & 4.198 & $(26.77)$ & 0.964 & $(8.21)$ & 0.883 & (7.37) & 0.896 & (7.63) \\
\hline Insider Ownership & & & -0.008 & $(-11.32)$ & -0.007 & $(-10.77)$ & -0.007 & $(-10.62)$ \\
\hline Block Ownership & & & -0.006 & $(-12.80)$ & -0.005 & $(-10.66)$ & -0.006 & $(-11.14)$ \\
\hline $\log ($ size $)$ & 0.267 & $(12.15)$ & 0.319 & (12.94) & 0.288 & $(11.70)$ & 0.280 & $(10.69)$ \\
\hline $\log (\mathrm{B} / \mathrm{M})$ & 0.554 & $(23.75)$ & 0.711 & (79.35) & 0.719 & (79.57) & 0.718 & $(76.64)$ \\
\hline ROA & 0.245 & $(8.78)$ & 0.361 & (16.68) & 0.362 & $(16.96)$ & 0.363 & $(16.80)$ \\
\hline Capex & 0.068 & (7.67) & 0.103 & $(9.16)$ & 0.104 & $(9.56)$ & 0.100 & (8.66) \\
\hline Cash & 0.000 & $(0.22)$ & 0.000 & $(-0.16)$ & 0.000 & $(-0.01)$ & 0.000 & $(-0.14)$ \\
\hline $\mathrm{D} / \mathrm{E}$ & -1.005 & $(-7.97)$ & -1.034 & $(-6.51)$ & -1.053 & $(-6.77)$ & -1.069 & $(-6.93)$ \\
\hline $\mathrm{P} / \mathrm{E}$ & 1.944 & (8.33) & 1.871 & (7.79) & 1.843 & $(7.76)$ & 1.926 & $(8.00)$ \\
\hline Growth of Sales & -0.217 & $(-5.35)$ & -0.082 & $(-2.64)$ & -0.085 & $(-2.77)$ & -0.084 & $(-2.77)$ \\
\hline Past Year Return & 71.986 & (13.46) & 45.014 & $(8.52)$ & 45.132 & $(8.49)$ & 46.533 & (8.86) \\
\hline Volatility & 0.662 & $(2.25)$ & -0.162 & $(-0.54)$ & -0.104 & $(-0.33)$ & -0.096 & $(-0.31)$ \\
\hline Industry Concentr. & -0.310 & $(-20.85)$ & -0.206 & $(-16.61)$ & -0.210 & $(-16.89)$ & -0.202 & $(-16.82)$ \\
\hline Industry FE & Yes & & Yes & & Yes & & Yes & \\
\hline State FE & Yes & & Yes & & Yes & & Yes & \\
\hline Clustering & State+Time & & State+Time & & State+Time & & State+Time & \\
\hline Adjusted $\mathrm{R}^{2}$ & 0.5251 & & 0.5974 & & 0.6028 & & 0.6023 & \\
\hline $\mathrm{N}$ & 16,846 & & 13,562 & & 13,562 & & 13,562 & \\
\hline
\end{tabular}




\section{Table 8: Passiveness and retail trading activity}

We relate passiveness of shareholder base to retail trading activity. We consider three measures aimed at capturing the trading activity of retail investors: the ratio of the number of retail trades to the number of total trades executed by all investors (Specifications (1) and (2)), the ratio of the number of shares traded by retail investors to the number of total shares traded by all investors (Specifications (3) and (4)), and the ratio of the dollar value of shares traded by retail investors to the total dollar value of shares traded by all investors (Specifications (5) and (6)). We classify retail investors' trades as those trades with less than 500 shares, using the convention of small trades adopted in Security and Exchange Commission's Rule 11Ac1-5 (i.e., Dash-5). Using the Trades and Quotes (TAQ) database produced by the New York Stock Exchange (NYSE), we first compute these ratios stock by stock on a daily basis, and then average these ratios with appropriate horizons. The data covers the 1992 to 2006 period. Panel A relates passiveness to the average daily retail trading activity over the subsequent year. Panel B reports on the relation between passiveness and average daily retail trading activity over $(0:+2)$ window around earnings announcements. All variables are described in Appendix 1.

\section{Panel A: Passiveness and average daily retail trading activity}

$(1)$

\begin{tabular}{|c|c|c|c|c|c|c|c|c|c|c|c|c|}
\hline & estimate & t-stat & estimate & t-stat & estimate & t-stat & estimate & t-stat & estimate & t-stat & estimate & t-stat \\
\hline Passiveness & -0.0073 & $(-6.77)$ & -0.0074 & $(-7.93)$ & -0.0048 & $(-8.51)$ & -0.0050 & $(-9.03)$ & -0.0053 & $(-8.63)$ & -0.0054 & $(-8.94)$ \\
\hline Inst. Ownership & 0.0871 & $(7.45)$ & 0.0894 & $(7.48)$ & 0.0511 & $(4.42)$ & 0.0523 & $(4.40)$ & 0.0466 & $(3.90)$ & 0.0478 & $(3.87)$ \\
\hline Insider Ownership & & & 0.0070 & $(0.91)$ & & & 0.0189 & $(3.36)$ & & & 0.0206 & $(3.29)$ \\
\hline Block Ownership & & & -0.0019 & $(-0.33)$ & & & 0.0066 & $(1.63)$ & & & 0.0086 & (1.94) \\
\hline $\log ($ size $)$ & 0.0331 & (20.32) & 0.0331 & $(21.43)$ & 0.0066 & $(4.40)$ & 0.0068 & $(4.65)$ & 0.0055 & $(3.39)$ & 0.0058 & $(3.67)$ \\
\hline $\log (\mathrm{B} / \mathrm{M})$ & 0.0060 & $(5.15)$ & 0.0060 & $(5.24)$ & 0.0044 & $(4.73)$ & 0.0043 & $(4.64)$ & 0.0055 & $(5.46)$ & 0.0053 & $(5.40)$ \\
\hline Past Year Return & -0.0043 & $(-2.02)$ & -0.0049 & $(-2.50)$ & 0.0071 & $(5.03)$ & 0.0061 & $(4.90)$ & 0.0090 & $(4.89)$ & 0.0078 & $(4.74)$ \\
\hline Volatility & -1.1479 & $(-6.56)$ & -1.1509 & $(-6.68)$ & -0.5163 & $(-4.10)$ & -0.5436 & $(-4.29)$ & -0.5808 & $(-3.84)$ & -0.6062 & $(-3.96)$ \\
\hline Stock Liquidity & 0.0012 & (1.37) & 0.0013 & $(1.42)$ & 0.0034 & $(3.86)$ & 0.0034 & $(3.80)$ & 0.0023 & $(2.35)$ & 0.0024 & $(2.36)$ \\
\hline Industry FE & $\mathrm{Sic} 2$ & & $\operatorname{Sic} 2$ & & Sic2 & & Sic2 & & Sic2 & & $\operatorname{Sic} 2$ & \\
\hline Time FE & Yes & & Yes & & Yes & & Yes & & Yes & & Yes & \\
\hline Clustering & Sic2 & & Sic2 & & Sic2 & & Sic2 & & Sic2 & & Sic2 & \\
\hline Adjusted $\mathrm{R}^{2}$ & 0.7286 & & 0.7277 & & 0.5985 & & 0.6051 & & 0.5746 & & 0.5806 & \\
\hline $\mathrm{N}$ & 59,453 & & 57,495 & & 59,453 & & 57,495 & & 59,439 & & 57,482 & \\
\hline
\end{tabular}


Panel B: Passiveness and retail trading activity around earnings announcements

(1)

\begin{tabular}{|c|c|c|c|c|c|c|c|c|c|c|c|c|}
\hline & & & & & & \\
\hline & estimate & t-stat & estimate & t-stat & estimate & t-stat & estimate & t-stat & estimate & t-stat & estimate & t-stat \\
\hline Passiveness & -0.0066 & $(-6.17)$ & -0.0061 & $(-6.81)$ & -0.0067 & $(-8.03)$ & -0.0060 & $(-7.46)$ & -0.0072 & $(-7.55)$ & -0.0063 & $(-6.64)$ \\
\hline Inst. Ownership & 0.0736 & $(5.68)$ & 0.0752 & $(5.64)$ & 0.0405 & $(3.40)$ & 0.0388 & $(3.13)$ & 0.0328 & $(2.56)$ & 0.0298 & $(2.21)$ \\
\hline Insider Ownership & & & 0.0059 & $(0.77)$ & & & 0.0167 & $(2.67)$ & & & 0.0213 & $(2.21)$ \\
\hline Block Ownership & & & 0.0045 & $(0.85)$ & & & 0.0198 & $(4.52)$ & & & 0.0269 & $(2.87)$ \\
\hline $\log ($ size $)$ & 0.0287 & $(22.11)$ & 0.0284 & $(21.93)$ & -0.0006 & $(-0.51)$ & -0.0006 & $(-0.49)$ & -0.0057 & $(-4.08)$ & -0.0055 & $(5.47)$ \\
\hline $\log (\mathrm{B} / \mathrm{M})$ & 0.0047 & $(3.45)$ & 0.0046 & $(3.40)$ & 0.0048 & $(3.46)$ & 0.0045 & $(3.22)$ & 0.0075 & $(4.41)$ & 0.0071 & $(-3.93)$ \\
\hline Past Year Return & 0.0319 & $(24.30)$ & 0.0327 & $(24.58)$ & 0.0250 & (21.04) & 0.0246 & $(21.60)$ & 0.0284 & (22.38) & 0.0278 & $(4.17)$ \\
\hline Volatility & -2.0865 & $(-11.14)$ & -2.1037 & $(-11.46)$ & -1.5858 & $(-9.21)$ & -1.6401 & $(-9.52)$ & -1.9010 & $(-8.80)$ & -1.9708 & (22.73) \\
\hline Stock Liquidity & 0.0005 & $(0.51)$ & 0.0009 & $(0.89)$ & -0.0003 & $(-0.23)$ & 0.0004 & $(0.34)$ & -0.0034 & $(-2.38)$ & -0.0026 & $(-9.09)$ \\
\hline Industry FE & Sic2 & & Sic2 & & Sic2 & & Sic2 & & Sic2 & & Sic2 & \\
\hline Time FE & Yes & & Yes & & Yes & & Yes & & Yes & & Yes & \\
\hline Clustering & Sic2 & & Sic2 & & Sic2 & & $\operatorname{Sic} 2$ & & Sic2 & & Sic2 & \\
\hline Adjusted $\mathrm{R}^{2}$ & 0.6155 & & 0.612 & & 0.4574 & & 0.4564 & & 0.3656 & & 0.3644 & \\
\hline $\mathrm{N}$ & 207,694 & & 202,677 & & 207,694 & & 202,677 & & 205,519 & & 200,544 & \\
\hline
\end{tabular}


Table 9: Passiveness and Tobin's $Q$

We relate passiveness to a firm's Tobin's Q at the end of the subsequent year. All variables are described in Appendix 1.

\begin{tabular}{|c|c|c|c|c|c|c|c|c|c|c|}
\hline & \multicolumn{2}{|c|}{ (1) } & \multicolumn{2}{|c|}{ (2) } & \multicolumn{2}{|c|}{ (3) } & \multicolumn{2}{|c|}{ (4) } & \multicolumn{2}{|c|}{ (5) } \\
\hline & estimate & t-stat & estimate & t-stat & estimate & t-stat & estimate & t-stat & estimate & t-stat \\
\hline Passiveness & -0.060 & $(-5.36)$ & -0.047 & $(-3.38)$ & & & & & & \\
\hline xHighIO & & & & & -0.019 & $(-1.20)$ & & & & \\
\hline$\times(1-\mathrm{HIghIO})$ & & & & & -0.071 & $(-4.44)$ & & & & \\
\hline$\times$ HighBlock & & & & & & & -0.012 & $(-1.01)$ & & \\
\hline × (1-HighBlock) & & & & & & & -0.103 & $(-4.77)$ & & \\
\hline$\times$ HighIO or High & lock or $\mathrm{H}$ & ighInside & & & & & & & -0.018 & $(-1.37)$ \\
\hline$\times(1-$ HighIO or $\mathrm{H}$ & ghBlock o & r HighInsi & side) & & & & & & -0.182 & $(-5.94)$ \\
\hline Inst. Ownership & -1.284 & $(-6.16)$ & -1.252 & $(-5.66)$ & -1.358 & $(-6.67)$ & -1.358 & $(-6.08)$ & -1.485 & $(-6.88)$ \\
\hline Insider Ownership & & & 0.129 & $(1.67)$ & 0.122 & $(1.61)$ & 0.127 & $(1.63)$ & 0.102 & $(1.40)$ \\
\hline Block Ownership & & & -0.551 & $(-6.23)$ & -0.545 & $(-6.17)$ & -0.631 & $(-7.18)$ & -0.573 & $(-6.76)$ \\
\hline $\log ($ size $)$ & 0.207 & $(6.98)$ & 0.192 & $(5.68)$ & 0.192 & $(5.76)$ & 0.208 & $(6.04)$ & 0.207 & (6.18) \\
\hline ROA & -0.019 & $(-2.61)$ & -0.017 & $(-2.93)$ & -0.017 & $(-2.92)$ & -0.017 & $(-2.91)$ & -0.017 & $(-2.92)$ \\
\hline Capex & 2.621 & $(6.19)$ & 2.960 & $(5.91)$ & 2.974 & $(5.96)$ & 2.913 & $(5.85)$ & 2.936 & $(5.90)$ \\
\hline Cash & 0.223 & $(5.19)$ & 0.169 & $(5.97)$ & 0.169 & $(6.06)$ & 0.167 & $(6.11)$ & 0.168 & $(6.30)$ \\
\hline $\mathrm{D} / \mathrm{E}$ & -0.092 & $(-6.87)$ & -0.086 & $(-5.62)$ & -0.086 & $(-5.59)$ & -0.085 & $(-5.56)$ & -0.085 & $(-5.59)$ \\
\hline $\mathrm{P} / \mathrm{E}$ & 0.000 & $(-0.45)$ & 0.000 & $(-0.53)$ & 0.000 & $(-0.51)$ & 0.000 & $(-0.52)$ & 0.000 & $(-0.48)$ \\
\hline Growth of Sales & 0.162 & $(2.49)$ & 0.113 & $(1.65)$ & 0.113 & $(1.66)$ & 0.105 & $(1.62)$ & 0.106 & $(1.64)$ \\
\hline Past Year Return & 0.307 & $(4.59)$ & 0.317 & $(4.18)$ & 0.321 & $(4.25)$ & 0.310 & $(4.11)$ & 0.314 & (4.15) \\
\hline Volatility & -1.804 & $(-1.76)$ & -5.583 & $(-3.82)$ & -5.893 & $(-4.06)$ & -5.327 & $(-3.61)$ & -5.788 & $(-4.03)$ \\
\hline Industry Concentr & -0.469 & $(-1.34)$ & -0.183 & $(-0.29)$ & -0.222 & $(-0.34)$ & -0.160 & $(-0.25)$ & -0.197 & $(-0.31)$ \\
\hline Stock Liquidity & 0.138 & (15.62) & 0.117 & (11.79) & 0.120 & (11.83) & 0.114 & $(11.38)$ & 0.120 & $(12.11)$ \\
\hline industry FE & Sic2 & & Sic2 & & Sic2 & & Sic2 & & Sic2 & \\
\hline Time FE & Yes & & Yes & & Yes & & Yes & & Yes & \\
\hline Clustering & Sic2 & & Sic2 & & Sic2 & & Sic2 & & Sic2 & \\
\hline Adjusted $\mathrm{R}^{2}$ & 0.2099 & & 0.2032 & & 0.2037 & & 0.2052 & & 0.2068 & \\
\hline $\mathrm{N}$ & 73,250 & & 35,881 & & 35,881 & & 35,881 & & 35,881 & \\
\hline
\end{tabular}




\section{Table R1: Inside ownership, institutional ownership, corporate governance, and passiveness}

We present the descriptive statistics of the relationship between insider ownership, institutional ownership, corporate governance, and shareholder passiveness. Each year companies are split into two groups by insider ownership/institutional ownership/corporate governance and two groups by shareholder passiveness. We report the percentage of firms falling into each of the four resulting groups. In Panel $\mathrm{C}$ we also report the average shareholder passiveness for different levels of the G governance index. All variables are described in Appendix 1.

Panel A: passiveness and insider ownership

insider ownership

\begin{tabular}{cccc}
\multirow{3}{*}{ Passiveness } & & low & High \\
\cline { 2 - 4 } & low & $19.10 \%$ & $30.90 \%$ \\
& high & $30.90 \%$ & $19.10 \%$ \\
\cline { 2 - 4 }
\end{tabular}

Panel B: passiveness and institutional ownership

\begin{tabular}{cccc} 
& & \multicolumn{2}{c}{ institutional ownership } \\
Passiveness & & low & High \\
\cline { 2 - 4 } & low & $34.55 \%$ & $15.45 \%$ \\
& high & $15.45 \%$ & $34.55 \%$ \\
\cline { 2 - 4 }
\end{tabular}

Panel C: passiveness and G-index

\begin{tabular}{|c|c|c|c|c|c|c|c|c|}
\hline \multirow[b]{3}{*}{ Passiveness } & \multicolumn{8}{|c|}{ G-index } \\
\hline & $\underline{1-5}$ & $\underline{6}$ & $\underline{7}$ & $\underline{8}$ & $\underline{9}$ & $\underline{10}$ & $\underline{11}$ & $\underline{12-18}$ \\
\hline & $1 . \overline{8371}$ & 2.0921 & 2.1928 & 2.4199 & 2.6072 & 2.8090 & 2.9947 & 3.1251 \\
\hline \multicolumn{9}{|c|}{$\underline{\text { G-index }}$} \\
\hline \multirow{3}{*}{ Passiveness } & & low & \multicolumn{2}{|c|}{ High } & & & & \\
\hline & low & $33.29 \%$ & \multicolumn{2}{|c|}{$23.07 \%$} & & & & \\
\hline & high & $16.71 \%$ & \multicolumn{2}{|c|}{$26.93 \%$} & & & & \\
\hline
\end{tabular}




\section{Table R2: Passiveness by industry}

We report the bottom 10 and top 10 SIC2-industries by average shareholder passiveness. All variables are described in Appendix 1.

Panel A: Bottom 10 industries by average passiveness

\begin{tabular}{clc} 
SIC2 & bottom 10 industries by average passiveness & Average passiveness \\
\hline 83 & social services & -0.8646 \\
31 & leather and leather products & 0.2320 \\
99 & nonclassifiable establishments & 0.2374 \\
22 & textile mill products & 0.2417 \\
82 & educational services & 0.3693 \\
73 & business services & 0.5210 \\
17 & construction special trade & 0.5337 \\
87 & engineering, accounting and related services & 0.5369 \\
38 & measuring, analyzing and controlling instruments & 0.5387 \\
28 & chemicals and allied products & 0.5737 \\
\hline
\end{tabular}

Panel B: Top 10 industries by average passiveness

\begin{tabular}{clc} 
SIC2 & top 10 industries by average passiveness & Average Passiveness \\
\hline 21 & tobacco products & 3.3358 \\
60 & depository institutions & 3.2058 \\
40 & railroad transportation & 3.1818 \\
49 & electric, gas and sanitary services & 3.1440 \\
53 & general merchandise stores & 3.1159 \\
29 & petroleum refining and related industries & 2.9090 \\
45 & transportation by air & 2.6425 \\
26 & paper and allied products & 2.5767 \\
75 & automotive repairs, services, and parking & 2.5391 \\
54 & food stores & 2.3437 \\
\hline
\end{tabular}

